\title{
Coarse fraction fluctuations in pelagic carbonate sediments from the tropical Indian Ocean: A 1500-kyr record of carbonate dissolution
}

\author{
Franck C. Bassinot, ${ }^{1,2}$ Luc Beaufort, ${ }^{1}$ Edith Vincent,, ${ }^{1}$ Laurent D. Labeyrie, ${ }^{3}$ \\ Frauke Rostek, ${ }^{1}$ Peter J. Müller, ${ }^{4}$ Xavier Quidelleur, ${ }^{5}$ and Yves Lancelot ${ }^{1}$
}

\begin{abstract}
We examined coarse fraction contents of pelagic carbonates deposited between 2000and 3700-m water depth in the tropical Indian Ocean using Ocean Drilling Program (ODP) sites 722 (Owen Ridge, Arabian Sea) and 758 (Ninetyeast Ridge, eastern equatorial Indian Ocean), and four giant piston cores collected by the French R/V Marion Dufresne during the SEYMAMA expedition. Over the last $1500 \mathrm{kyr}$, coarse fraction records display high-amplitude oscillations with an irregular wavelength on the order of $\sim 500 \mathrm{kyr}$. These oscillations can be correlated throughout the entire equatorial Indian Ocean, from the Seychelles area eastward to the Ninetyeast Ridge, and into the Arabian Sea. Changes in grain size mainly result from changes in carbonate dissolution as evidenced by the positive relationship between coarse fraction content and a foraminiferal preservation index based on test fragmentation. The well-known "mid-Brunhes dissolution cycle" represents the last part of this irregular long-term dissolution oscillation. The origin of this longterm oscillation is still poorly understood. Our observations suggest that it is not a true cycle (it has an irregular wavelength) and we propose that it may result from long-term changes in $\mathrm{Ca}^{++}$flux to the ocean. Sites 722 and $758 \delta^{18} \mathrm{O}$ records provide a high-resolution stratigraphy that allows a detailed intersite comparison of the two coarse fraction records over the last $1500 \mathrm{kyr}$. Site 722 $(2030 \mathrm{~m})$ lies above the present and late Pleistocene lysocline. The lysocline shoaled to the position of site $758(2925 \mathrm{~m})$ only during the interglacial intervals that occurred between about 300 and $500 \mathrm{ka}$ (Peterson and Prell, 1985a). Despite these supralysoclinal positions of the two sites, short-term changes in coarse fraction contents are correlatable from one site to another and probably result from regional (or global) dissolution pulses. By stacking the normalized coarse fraction records from sites 722 and 758, we constructed a Composite Coarse Fraction Index (CCFI) curve in which most of the local signals cancelled out. The last $800 \mathrm{kyr}$ of this curve appear to compare extremely well with the Composite Dissolution Index curve from core V34-53 (Ninetyeast Ridge), which unambiguously records past variations of carbonate dissolution in the equatorial Indian Ocean (Peterson and Prell, 1985a). In the late Pleistocene the CCFI variations are mainly associated with glacial-interglacial changes. They show strong 100 and 41 kyr periodicities but no clear precession-related periodicities. As proposed earlier by Peterson and Prell (1985a), the lack of precession frequencies may suggest that the regional carbonate dissolution signal is driven by changes in deepwater circulation. We cannot totally reject the possibility, however, that low temporal resolution and/or bioturbation degrade somehow the precessional signal at ODP sites 722 and 758. In contrast, spectral density of dissolution cycles in the giant (53 m long) piston core MD900963 (Maldives area) displays clear maxima centered on the precession frequencies (23 and 19 $\mathrm{kyr}^{-1}$ ) as well as on the $29-\mathrm{kyr}^{-1}$ frequency but shows little power at the $100-\mathrm{kyr}^{-1}$ frequency. These high-frequency changes most probably result from changes in surface productivity associated with monsoon variability. Dissolution at this site may be ultimately controlled by the oxidation of organic matter which appears to be incorporated into the sediments in greater quantity during periods of weak SW monsoon and/or increased dry NE monsoon.
\end{abstract}

\footnotetext{
${ }^{1}$ Laboratoire de Géologie du Quaternaire, Centre National de la Recherche Scientifique, Marseille, France.

${ }^{2}$ Now at Centre des Faibles Radioactivités, Domaine du Centre National de la Recherche Scientifique, Gif-sur-Yvette, France.

${ }^{3}$ Centre des Faibles Radioactivités, Domaine du Centre National de la Recherche Scientifique, Gif-sur-Yvette, France.

${ }^{4}$ Geowissenschaften, Universität Bremen, Bremen, Germany.

${ }^{5}$ Institut de Physique du Globe de Paris, Paris, France.
}

Copyright 1994 by the American Geophysical Union.

Paper number 94PA00860.

0883-8305/94/94PA-00860\$10.00

\section{Introduction}

Deep-sea carbonate sediments cover about one half of the total oceanic floor [Berger et al., 1976; Biscaye et al., 1976; Kolla et al., 1976] and act as a large and reactive reservoir for carbon dioxide [Broecker and Peng, 1982, 1987; Sundquist and Broecker, 1985]. Understanding temporal and spatial changes in carbonate preservation is of key importance for testing the numerous models which seek to explain past changes in atmospheric $\mathrm{pCO}_{2}$ through changes in the oceanic carboncarbonate system [Broecker, 1982; Broecker and Peng, 1982; Boyle, 1988; Keir, 1988]. 
Since the pioneering work of Arrhenius [1952], it has been clearly established that carbonate contents of equatorial pelagic sediments show cyclic variations associated with Pleistocene glacial-interglacial changes [e.g., Arrhenius, 1952; Broecker, 1971; Berger, 1973; Gardner, 1975; Moore et al., 1982; Crowley, 1985; Peterson and Prell, 1985a; Vincent, 1985; Arrhenius, 1988; Farrell and Prell, 1989; Berger, 1992]. These fluctuations have been correlated over large distances in the Pacific [Hays et al., 1969; Vincent, 1981; Karlin et al., 1992] and into the Indian Ocean [Volat et al., 1980; Vincent, 1985] and have been used as powerful geochemical correlation tools. First interpreted in terms of changing surface productivity [Arrhenius, 1952], the Indo-Pacific carbonate fluctuations have been later reinterpreted in terms of dissolution changes, with increased dissolution during interglacials and enhanced preservation during glacials [Berger, 1973; Thompson and Saito, 1974; Volat et al., 1980; Farrell and Prell, 1989] (see the review by Berger [1992]). In the Atlantic and Southern Oceans, dissolution generally intensified during glacial periods [Gardner, 1975; Bé et al., 1976; Crowley, 1983; Howard and Prell, 1990]. This asymmetry between the Atlantic and the Indo-Pacific has been attributed to changes in basin-basin fractionation resulting from variations in North Atlantic Deep Water (NADW) formation [Berger, 1970; Volat et al., 1980; Crowley, 1985].

Most studies dealing with carbonate dissolution history have focused on deep-sea records below the calcite lysocline, where past changes in carbonate saturation of seawater have resulted in high-amplitude changes in carbonate content or in calcareous microfossil preservation [Berger, 1973; Thompson and Saito, 1974; Luz and Shackleton, 1975; Adelseck, 1977; Mayer, 1979; Peterson and Prell, 1985a; Farrell and Prell, 1989]. There is far less data available for carbonate dissolution cycles in "shallower" water depths (above the lysocline) [Droxler et al., 1983, 1990; Haddad, 1986]. Although supralysoclinal waters are supersaturated with respect to calcite, sediments deposited above the lysocline undergo significant carbonate dissolution. It has been proposed that this dissolution results from the decay of organic matter [Emerson and Bender, 1981; Peterson and Prell, 1985b], with the release of $\mathrm{CO}_{2}$ reducing the pore water carbonate ion concentration to a level lower than at the equivalent water depth in the water column. Carbonate dissolution patterns at intermediate and shallow water depths are of key importance in determining whether past changes in the oceanic carboncarbonate system indicate a redistribution of properties within the ocean during glacial/interglacial oscillations [e.g., Boyle, 1988], or indicate transfers between global carbon or carbonate reservoirs (shelf, soil, and biosphere) that affect the entire water column in a similar way [e.g., Berger, 1970; Shackleton, 1977; Broecker, 1982].

With increasing dissolution, foraminiferal tests tend to break down into small fragments [Berger, 1968; Bé et al., 1975; Thunell, 1976]. Detailed depth transect studies conducted on the Ontong Java Plateau (western equatorial Pacific) and upon the Ninetyeast Ridge (eastern equatorial Indian Ocean) have clearly established that coarse fraction contents show a systematic relationship with water depth, which mainly results from the fragmentation of foraminifera and the subsequent transfer of fragments to the finer size fraction as dissolution proceeds [Johnson et al., 1977; Berger et al., 1982; Peterson and Prell, 1985b]. Decrease in coarse fraction content is a much more sensitive indicator of dissolution than carbonate content, because foraminiferal tests can break down after a small amount of carbonate has been lost to dissolution. For instance, some $60 \%$ of the whole sand-sized planktonic foraminifera has already broken up at the lysocline level upon Ninetyeast Ridge, whereas no more than 20 to $30 \%$ of total carbonate has been estimated to have been lost to dissolution [Peterson and Prell, 1985b]. Thus coarse fraction records should provide relatively easy to obtain qualitative information on the dissolution history in supralysoclinal carbonate deposits. The purpose of this study is to present a detailed coarse fraction stratigraphy of Pleistocene carbonate sediments from the tropical Indian Ocean to test the potential of grain size data as a correlation tool and as a proxy for studies of supralysoclinal carbonate dissolution.

\section{Study Area, Material, and Methods}

We selected four giant piston cores (30 to $53 \mathrm{~m}$ in length) retrieved during the SEYMAMA expedition of the French R/V Marion Dufresne (cores MD900938, MD900940, MD900949, and MD900963) and two Ocean Drilling Program (ODP) sites (sites 722 and 758). These pelagic carbonate sections are distributed over much of the tropical Indian Ocean in water depths ranging from 2030 to $3700 \mathrm{~m}$ (Figure 1 and Table 1). They provide long, continuous, and undisturbed PlioPleistocene coarse fraction records.

Sites 722 (Owen Ridge, Arabian Sea) and 758 (Ninetyeast Ridge, eastern equatorial Indian Ocean) are especially suitable for studying temporal changes in coarse fraction content above the lysocline. Sites $722(2030 \mathrm{~m})$ and $758(2925 \mathrm{~m})$ lie about 1300 and $900 \mathrm{~m}$ above the present foraminiferal lysocline in the Arabian Sea [Cullen and Prell, 1984] and in the eastern equatorial Indian Ocean [Peterson and Prell, 1985b], respectively. On Ninetyeast Ridge the present foraminiferal lysocline (at $3800 \mathrm{~m}$ ) is close to the saturation horizon with respect to calcite in the water column [Peterson and Prell, 1985b]. The lysocline position in the Ninetyeast Ridge area varied between about $2800 \mathrm{~m}$ and $4200 \mathrm{~m}$ during the last 800 $\mathrm{kyr}$, that is to say, plus $400 \mathrm{~m}$ or minus $1000 \mathrm{~m}$ around its present position in the water column [Peterson and Prell, 1985a]. The lysocline shoaled to the position of site 758 only during the interglacial intervals that occurred between about 300 and $500 \mathrm{ka}$. If we consider that the lysocline position at Owen Ridge may have roughly fluctuated with the same amplitude, then site 722 probably remained in a supralysoclinal position during the entire late Pleistocene.

At sites 722 and 758, continuous sedimentary sections have been previously constructed by splicing across recovery gaps the 9.5-m-long hydraulic piston cores retrieved in adjacent holes from the same site [Murray and Prell, 1991; Farrell and Janecek, 1991, respectively]. Sedimentological data (proportion of fraction $>150 \mu \mathrm{m}$ obtained by wet-sieving and $\mathrm{CaCO}_{3}$ content) and oxygen isotope data obtained on planktonic foraminifera were also taken from Murray and Prell [1991] and Farrell and Janecek [1991].

In the SEYMAMA cores, sediments were sampled at a $10-\mathrm{cm}$ interval. Carbonate content was measured on cores MD900938, MD900949, and MD900963 using a modified "Bernard calcimeter." We estimated the accuracy of the method 


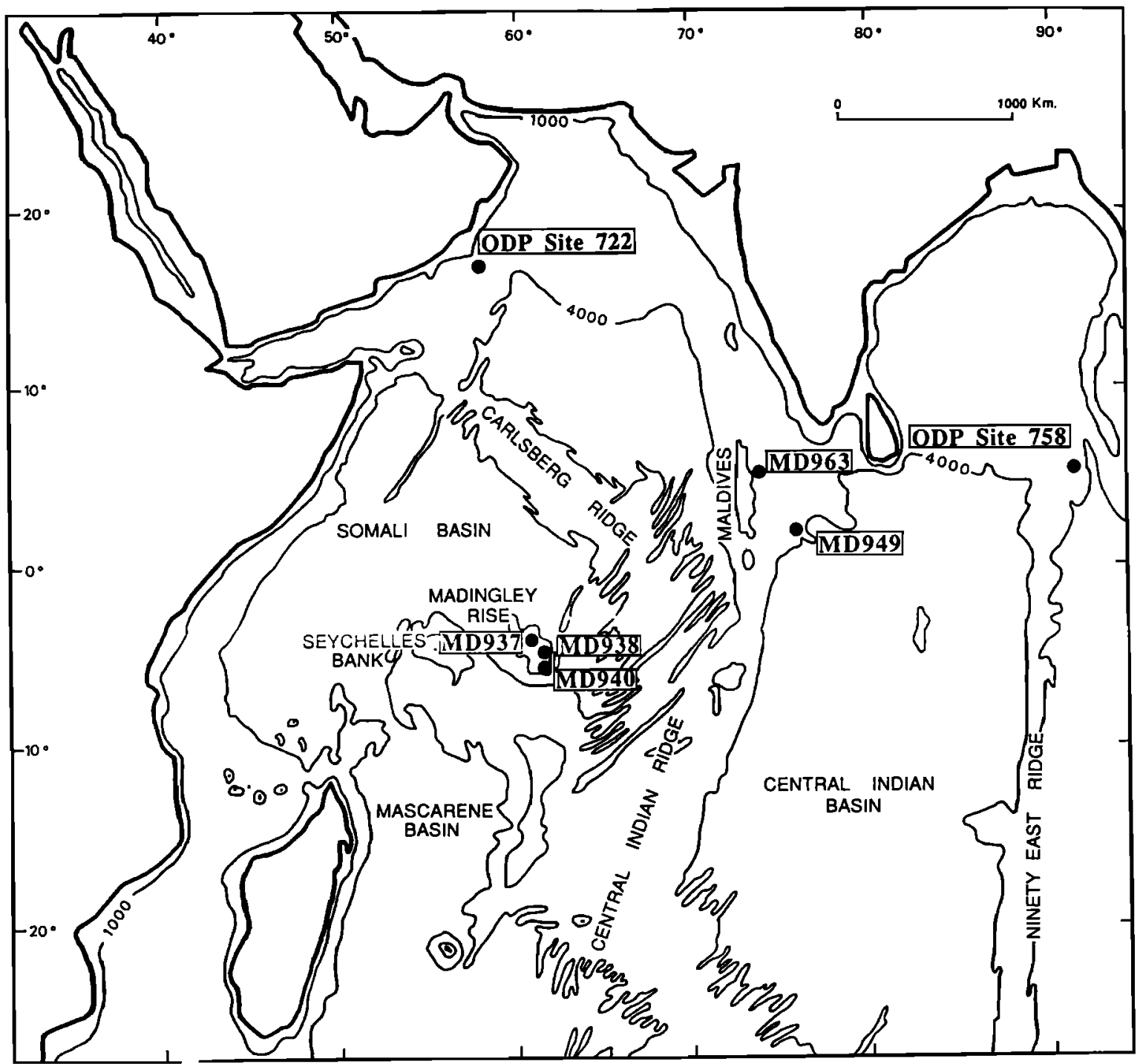

Figure 1. Location map showing positions of SEYMAMA giant piston cores and Ocean Drilling Program (ODP) sites used in this study. Bathymetric contours are in meters. Note that identification numbers of SEYMAMA cores were shortened in this figure for convenience (e.g., MD938 instead of MD900938).

Table 1. Location and Water Dept of Piston Cores Retrieved During the SEYMANA Cruise of the French $\mathrm{R} / \mathrm{V}$ Marion Dufresene in the Equatorial Indian Ocean, and of Ocean Drilling Program Site 572 (Equatorial Pacific), and 722 and 758 (Tropical Indian Ocean)

\begin{tabular}{|c|c|c|c|}
\hline Cores/Sites & Latitude & Longitude & $\begin{array}{l}\text { Water } \\
\text { Depth, m }\end{array}$ \\
\hline $\begin{array}{l}\text { MD900938 } \\
\text { MD900940 } \\
\text { MD900949 } \\
\text { MD900963 } \\
\text { ODP site } 722 \\
\text { ODP site } 758 \\
\text { ODP site } 572\end{array}$ & $\begin{array}{l}04^{\circ} 57^{\prime} 90^{\prime \prime} \mathrm{S} \\
05^{\circ} 33^{\prime} 53^{\prime \prime} \mathrm{S} \\
02^{\circ} 05^{\prime} 43^{\prime \prime} \mathrm{N} \\
05^{\circ} 03^{\prime} 30^{\prime \prime} \mathrm{N} \\
16^{\circ} 37^{\prime} 30^{\prime \prime} \mathrm{N} \\
05^{\circ} 23^{\prime} 05^{\prime \prime} \mathrm{N} \\
01^{\circ} 26^{\prime} 09^{\prime \prime} \mathrm{N}\end{array}$ & $\begin{array}{l}60^{\circ} 04^{\prime} 44^{\prime \prime} \mathrm{E} \\
61^{\circ} 40^{\prime} 12^{\prime \prime} \mathrm{E} \\
76^{\circ} 06^{\prime} 96^{\prime \prime} \mathrm{E} \\
73^{\circ} 52^{\prime} 60^{\prime \prime} \mathrm{E} \\
59^{\circ} 47^{\prime} 80^{\prime \prime} \mathrm{E} \\
90^{\circ} 21^{\prime} 67^{\prime \prime} \mathrm{E} \\
11^{\circ} 50^{\prime} 52^{\prime \prime} \mathrm{W}\end{array}$ & $\begin{array}{l}3430 \\
3190 \\
3700 \\
2446 \\
2030 \\
2925 \\
3900\end{array}$ \\
\hline
\end{tabular}

to be within $\pm 2-3 \%$ for carbonate contents ranging from 50 to $100 \%$. Coarse fraction contents were obtained in all SEYMAMA cores through wet-sieving over a $63-\mu \mathrm{m}$ mesh sieve. In core MD900938, we also measured relative abundances of the $>250$ - and $>350-\mu \mathrm{m}$ fractions to test if there are important differences in the interpretation of coarse fraction records based on a different size. It is important to address correctly this point, since we will compare $>150-\mu \mathrm{m}$ grain size records (sites 722 and 758 ) with $>63-\mu \mathrm{m}$ records (SEYMAMA cores).

In cores MD900938, MD900949, and MD900963, we subsieved the fraction coarser than $63 \mu \mathrm{m}$ using a $250-\mu \mathrm{m}$ and a $355-\mu \mathrm{m}$ mesh sieve in order to isolate large foraminifera for later stable isotopic studies. In these three cores, we examined the fragmentation of planktonic foraminifera in the 250- to $355-\mu \mathrm{m}$ size fraction. Results are expressed in the form of a "preservation index" calculated as the percentage of whole 
foraminifera to fragments plus whole foraminifera. In core MD900938 and MD900949, fragmentation was measured at $20-\mathrm{cm}$ intervals, and in core MD900963 it was measured at 10cm intervals.

Foraminiferal fragmentation is one of the most reliable indices of carbonate dissolution [Bé et al., 1975; Thunell, 1976; Peterson and Prell, 1985b; Le and Shackleton, 1992]. The large size of particles in the 250 - to $355-\mu \mathrm{m}$ size fraction makes the counting of fragments a relatively easy task to perform. However, we were aware that foraminiferal fragments in such a small size range may not be numerous enough to get a good statistical measure of dissolution intensity. In core MD900938, to test the sensitivity of our index, we compared results obtained in the 250 - to $355-\mu \mathrm{m}$ size fraction with fragmentation measured in the $>150-\mu \mathrm{m}$ size fraction, since this latter fraction is the most commonly used in foraminiferal fragmentation studies [e.g., Peterson and Prell, 1985b].

In core MD900963, oxygen stable isotopes were measured at the isotope geochemistry laboratory of the Centre des Faibles Radioactivités, Gif-sur-Yvette, France, on the planktonic foraminifera Globigerinoides ruber (white) picked from the $250-$ to $355-\mu \mathrm{m}$ size fraction. The mass spectrometer is a Finnigan MAT-251 model with an automated carbonate preparation system (individual reaction chambers device). The data are all reported with respect to the Pee Dee belemnite standard. (Carbonate content, grain size, foraminifer frag- ments, and $\delta^{18} \mathrm{O}$ data are available in the Calcium Carbonate Database, National Geophysical Data Center, Boulder, Colorado, at paleo@mail.ngdc.noaa.gov).

Paleomagnetic measurements were performed on standard cubes $\left(8 \mathrm{~cm}^{3}\right)$ every $75 \mathrm{~cm}$ along core MD900963, with the mean sampling interval then reduced to about $12 \mathrm{~cm}$ around the Brunhes/Matuyama magnetic reversal. The measurements and stepwise demagnetizations of the natural remanent magnetization (NRM) were performed within the shielded room of the Institut de Physique du Globe de Paris, France. NRM values are low but declination is interpretable.

In the uppermost $10 \mathrm{~m}$ of core MD900963, organic carbon measurements were carried out at intervals of $10 \mathrm{~cm}$ at the Department of Geoscience of the University of Bremen, Germany, using a Carbone-Hydrogen-Nitrogen analyzer. Sample preparation and technical details are described elsewhere [Müller et al., 1994].

\section{Chronological Framework}

\section{Chronological Framework Based on Biostratigraphy and Magnetostratigraphy}

At all sites, we were able to develop a coarse chronological framework for the past $\mathbf{2 5 0 0} \mathbf{k y r}$ based on magnetic reversal stratigraphy and/or calcareous microfossil events (Table 2).

Table 2. Calcareous Microfossil Datums and Magnetostratigraphic Events Used for the Depth-to-Time Conversions in SEYMANA Cores MD900938, MD900940, MD900949, and MD900963, and ODP Sites 722 and 758

\begin{tabular}{|c|c|c|c|c|c|c|c|c|}
\hline \multirow{2}{*}{$\begin{array}{l}\text { Stratigraphic Events } \\
\text { Acme Emiliania huxleyi }\end{array}$} & \multicolumn{2}{|c|}{$\begin{array}{l}\text { Age, } \\
\text { Ma }\end{array}$} & \multirow[t]{2}{*}{$\begin{array}{c}\text { MD938, } \\
\mathrm{m}\end{array}$} & \multirow[t]{3}{*}{$\begin{array}{c}\text { MD940, } \\
\text { m }\end{array}$} & \multirow[t]{3}{*}{$\begin{array}{c}\text { MD949, } \\
\mathrm{m}\end{array}$} & \multirow{2}{*}{$\begin{array}{c}\begin{array}{c}\text { MD963, } \\
\mathrm{m}\end{array} \\
3.80\end{array}$} & \multirow[t]{2}{*}{$\underset{\mathrm{m}}{\text { Site }} 722$} & \multirow{2}{*}{$\begin{array}{c}\text { Site } 758 \\
\mathrm{~m}\end{array}$} \\
\hline & 0.073 & (1) & & & & & & \\
\hline FO Emiliania huxleyi & 0.28 & (1) & & & & & 7.95 & \\
\hline LO Pseudoemiliania lacunosa & 0.47 & (1) & 7.85 & 6.15 & 13.35 & 21.70 & 18.90 & \\
\hline Brunhes/Matuyama & 0.78 & (2) & & & & 35.10 & 28.00 & 12.17 \\
\hline LO Reticulofenestra asanoi & 0.88 & (3) & 13.55 & 11.15 & 22.35 & 38.38 & $\ldots$ & \\
\hline Top Jaramillo & 0.99 & (2) & & & & $\ldots$ & . & 15.57 \\
\hline Rejuven. Gephyrocapsa oceanica & 1.028 & (4) & 15.95 & 12.55 & 25.71 & $\ldots$ & & \\
\hline Base Jaramillo & 1.07 & (2) & & & & $\cdots$ & 40.35 & 16.77 \\
\hline LO large Gephyrocapsa oceanica & 1.24 & (4) & 18.06 & 15.15 & 30.55 & & $\ldots$ & $\ldots$ \\
\hline LO Helicosphaera sellii & 1.47 & (4) & 19.17 & 17.71 & 35.00 & 41.09 & & . \\
\hline LO Calcidiscus macintyrei & 1.59 & (4) & 20.62 & 18.56 & & 41.09 & 55.55 & $\ldots$ \\
\hline FO Gephyrocapsa oceanica & 1.67 & (4) & $\ldots$ & & & 41.09 & $\ldots$ & $\ldots$ \\
\hline LO Globigerinoides fistulosus & 1.73 & (5) & $\ldots$ & $\ldots$ & & 41.20 & $\ldots$ & $\ldots$ \\
\hline Top Olduvai & 1.77 & (2) & & & & 41.20 & & $\ldots$ \\
\hline LO Discoaster brouweri & 1.95 & (4) & 24.45 & 20.65 & & 51.00 & 69.50 & $\ldots$ \\
\hline LO Discoaster assymetricus & 2.26 & (6) & 29.45 & & & & & \\
\hline Matuyama/Gauss & 2.60 & (2) & & $\ldots$ & & & 89.40 & 38.53 \\
\hline
\end{tabular}

Biostratigraphic analyses for SEYMAMA cores were performed at the Laboratoire de Géologie du Quaternaire (Centre National de la Recherche Scientifique, Marseille, France); biostratigraphic and magnetostratigraphic events for ODP sites are from the shipboard parties of legs 117 and 121, respectively [Peirce et al., 1991; Prell et al., 1991]. Depth positions in the final, spliced depth scales of sites 722 and 758 were taken from Murray and Prell [1991] and Farrell and Janecek [1991], respectively. FO, first occurrence, LO, last occurrence. Ages are (1) from Berggren et al. [1985], (2) from Shackleton et al. [1990], (3) from Wei [1993], (4) from Raffi et al. [1993], (5) estimated according to the disappearance of G. fistulosus at site 677 and the orbital chronology developed at this site by Shackleton et al. [1990], and (6) calculated by linear interpolation between ages of magnetic reversals from Shackleton et al. [1990] with position of the datum given by Berggren et al. [1985]. 
For sites 722 and 758, biostratigraphic and magnetostratigraphic events are those determined during shipboard analysis. Positions of these selected stratigraphic events in the spliced depth scale are given by Murray and Prell [1991] and Farrell and Janecek [1991]. In the SEYMAMA cores, the positions of calcareous microfossil events have been determined with a $10-\mathrm{cm}$ sampling interval. The Brunhes/Matuyama magnetic polarity reversal has been identified in core MD900963 at a depth of $35 \pm 0.3 \mathrm{~m}$.

Time-to-depth conversions (Figure 2) were performed by assuming constant sedimentation rates between control points (Table 2). Ages of magnetic reversals are from estimates by Shackleton et al. [1990]. Ages of calcareous nannofossil events are derived from recent calibration of nannofossil biostratigraphy to oxygen isotope stratigraphies [Raffi et al., 1993; Wei, 1993]. Some nannofossil events have been shown to be diachronous between low- and mid-latitude sites [Raffi et al., 1993]. Because we are dealing with low-latitude sites in this paper, we use age estimates based on calibration to

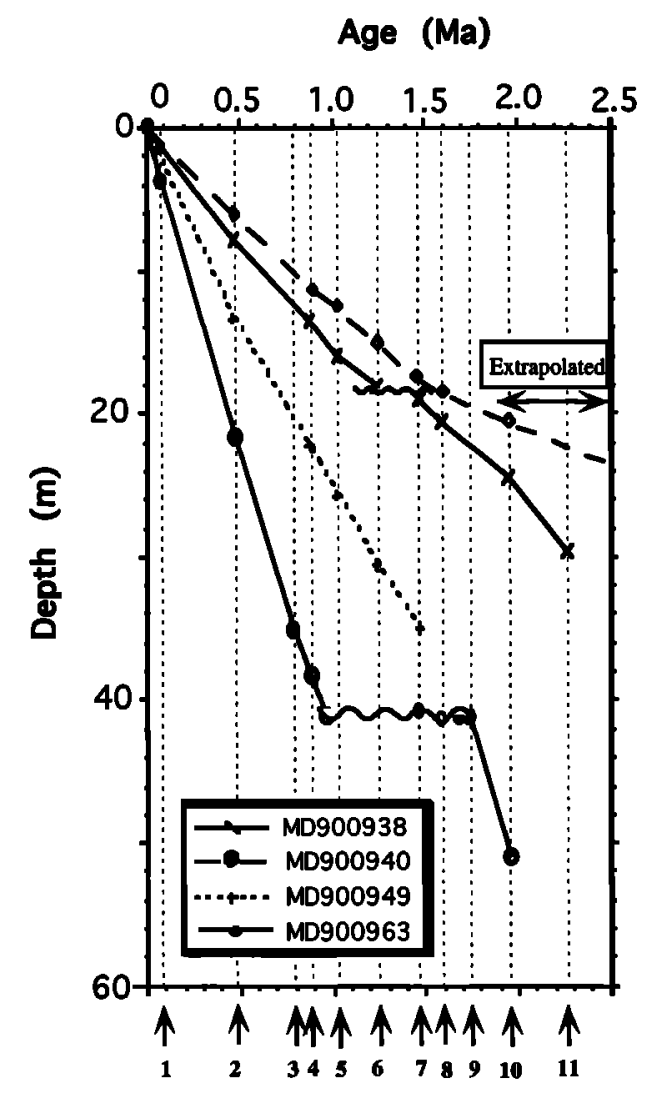

Figure 2. Age-depth plots showing sedimentation rates in cores MD900938 and MD900940 (Madingley Rise, western equatorial Indian Ocean) and in cores MD900949 and MD900963 (central equatorial Indian Ocean): 1, first occurrence (FO) Emiliania huxleyi; 2, last occurrence (LO) Pseudoemiliania lacunosa; 3, Brunhes/Matuyama reversal; 4, LO Reticulofenestra asanoï; 5, rejuvenation of large Gephyrocapsa oceanica; 6, decrease of the abundance in large G. oceanica; 7, LO Helicosphaera sellii; 8, LO Calcidiscus macintyrei; 9, LO Globigerinoides fistulosus; 10, LO Discoaster brouweri; 11, LO Discoaster assymetricus. oxygen isotope stratigraphy from Ocean Drilling Program (ODP) site 677. The last occurrence of Globigerinoides fistulosus occurs in the oxygen isotopic stage 61 (at $70.6 \mathrm{~m}$ ) in site 677 and is dated at $1.73 \mathrm{Ma}$ based on the orbitally derived chronology developed at this site by Shackleton et al. [1990]. Depth-age curves for the SEYMAMA cores are shown in Figure 2.

The depositional history of core MD900963 records a major hiatus at about $41 \mathrm{~m}$ (Figure 2), as shown by the concomitant disappearance at this level of Helicosphaera sellii, Calcidiscus macintyrei, and $G$. fistulosus and by the first appearance of Gephyrocapsa oceanica. The ages of these biostratigraphic datums span the time interval from $1.73 \mathrm{Ma}$ to $1.47 \mathrm{Ma}$, which gives the minimum duration of the hiatus. We interpret, however, the hiatus as spanning 770,000 years between 1.73 $\mathrm{Ma}$ at its base (dated by the last occurrence of $G$. fistulosus) and $0.96 \mathrm{Ma}$ at its top (dated by extrapolating downcore the sedimentation rates calculated between the Brunhes/Matuyama reversal and the last occurrence of Reticulofenestra asanoi).

In core MD900938, a step in the depth-age curve is observed between the last occurrence of $H$. sellii $(1.47 \mathrm{Ma}$ at $19.17 \mathrm{~m}$ ) and the disappearance of large Gephyrocapsa oceanica (1.24 Ma at $18.06 \mathrm{~m}$ ) (Figure 2). It is unlikely that there is continuous sedimentation in this short depth interval. We interpret this interval as containing a hiatus at about 18.60 $\mathrm{m}$, spanning almost totally the time interval (230,000 years) between the two biostratigraphic events (Figure 2).

\section{Oxygen Isotope Stratigraphy and Orbital Chronology}

We constructed more detailed age models based on planktonic foraminiferal $\delta^{18} \mathrm{O}$ in SEYMAMA core MD900963 and ODP sites 722 and 758 . These age models will permit more precise intersite comparisons of the coarse fraction records from these three series. The chronology for these isotopic age models was developed from site 677 [Shackleton et al., 1990]. Thus age models from sites 722 and 758 differ from those proposed by Murray and Prell [1991] and Farrel and Janecek [1991], respectively, which rested upon correlation to the SPECMAP curve [Imbrie et al., 1984] and to the orbitally tuned record from ODP site 607 [Ruddiman et al., 1989].

We aligned features in our $\delta^{18} \mathrm{O}$ records with features in the site 677 record using the program "LINAGE" developed by D. Paillard and L. Labeyrie at the Centre des Faibles Radioactivités. In our correlation processes, the $\delta^{18} \mathrm{O}$ transitions (stage boundaries) were given higher priorities than the centers of glacials and interglacials. The sedimentation rates are assumed to be constant between selected age control points and to change more or less abruptly at these control points. Such an assumption is probably quite correct when control points correspond to isotopic transitions, where environmental changes are supposed to affect the sedimentation rates decisively. Furthermore, as stated recently by Le and Shackleton [1992], locating a rapid change with a large amplitude (stage boundary) is probably more accurate than positioning a peak or trough with considerable width and small amplitude in comparison with analytical noise (centers of glacials or interglacials).

Correlations are easy in the Brunhes chronozones because of the characteristic glacial-interglacial $100-k y r$ cycles. In the 
early Pleistocene, however, the low-amplitude 41-kyr $\delta^{18} \mathrm{O}$ cycles typical of this time interval [e.g., Prell, 1982; Ruddiman et al., 1986] are much more difficult to correlate with confidence. In this interval, the base of the Jaramillo subchronozone, recognized at sites 722 and 758, provides an additional control point for ensuring intersite $\delta^{18} \mathrm{O}$ correlations.

\section{Results and Discussion}

\section{Coarse Fraction Records From the Equatorial Indian Ocean and Carbonate Dissolution Fluctuations}

Except for a few ash layers encountered at site 758 [Farrell and Janecek, 1991], carbonate contents range roughly from about 40 to $80 \%$ in cores MD900949 and MD900963 and in sites 722 and 758 (Figure 3). Core MD900938 shows higher carbonate contents, ranging from about 80 to $95 \%$. Sediments mainly consist of calcareous nannofossil oozes with varying amounts of foraminifera. Sediments retrieved at site 722 and core MD900963, however, are not "typical" open sea pelagic carbonates. Site 722 was cored in an area strongly affected by monsoonal winds and is close to the Arabian coast. Consequently, carbonate contents reflect the dilution by terrigeneous material, largely eolian in origin, coming from nearby arid land masses [Murray and Prell, 1991]. Core MD900963 was retrieved on the eastern shoulder of the Maldives Ridge. Besides calcareous planktonic particles, the sediments at this location also contain bank-derived aragonite needles (aragonite content averages $8 \%$ with a standard deviation of $10 \%$ (G. Haddad, personal communication, 1992)) which are typical of periplatform carbonate deposits [e.g., Kier and Pilkey, 1971; Schlager and James, 1978; Droxler et al., 1983, 1990; Boardman and Neumann, 1984].
Coarse fraction records from all sites are plotted versus age for the last $2500 \mathrm{kyr}$ (Figure 4). Ages are those derived from biostratigraphic and magnetostratigraphic age models (Table 2). In sediments older than about $1500 \mathrm{ka}$, grain size varied with only low amplitudes. The fluctuations do not appear to be easily correlatable among all the sites (except between cores MD900938 and MD900940, which were retrieved about 100 km apart on Madingley Rise (Figure 1 and Table 1)). At about 1300-1500 ka, coarse fraction records show the onset of a high-amplitude, long-term oscillation. Minima and maxima of this oscillation appear to be roughly correlatable across the entire tropical Indian Ocean. Minima are centered at about 300$500 \mathrm{ka}$ and 900-1000 ka, and maxima are centered at about $100-200 \mathrm{ka}, 700-800 \mathrm{ka}$, and 1100-1300 ka.

The coarse fraction from these sediments consists almost exclusively of sand-sized foraminifera (radiolarians are usually $<10 \%$ ). Past changes in the coarse fraction abundance in these sediments may reflect (1) ecological factors, such as past changes in the mean size of foraminifera or changes in the foraminifera to nannofossils ratio [Briggs et al., 1985; Mienert and Bloemendal, 1989], or (2) sedimentological factors, such as carbonate dissolution [Berger et al., 1982; Peterson and Prell, 1985b], changes in the winnowing intensity at the seafloor which preferentially removes fines and leaves coarse particles [Wu and Berger, 1991; Mayer et al., 1993], or changes in dilution by fine-grained, nonbiogenic particles.

A positive relationship between coarse fraction content and foraminiferal preservation has been previously observed at site 758 [Chen and Farrell, 1991], thus clearly arguing for a control by carbonate dissolution. We examined the fragmentation of planktonic foraminifera in the 250 - to $355-\mu \mathrm{m}$ size fraction in cores MD900938, MD900949, and MD900963. In core MD900938, fragmentation was also measured in the $>150 \mu \mathrm{m}$ fraction. The strong correlation between our preservation

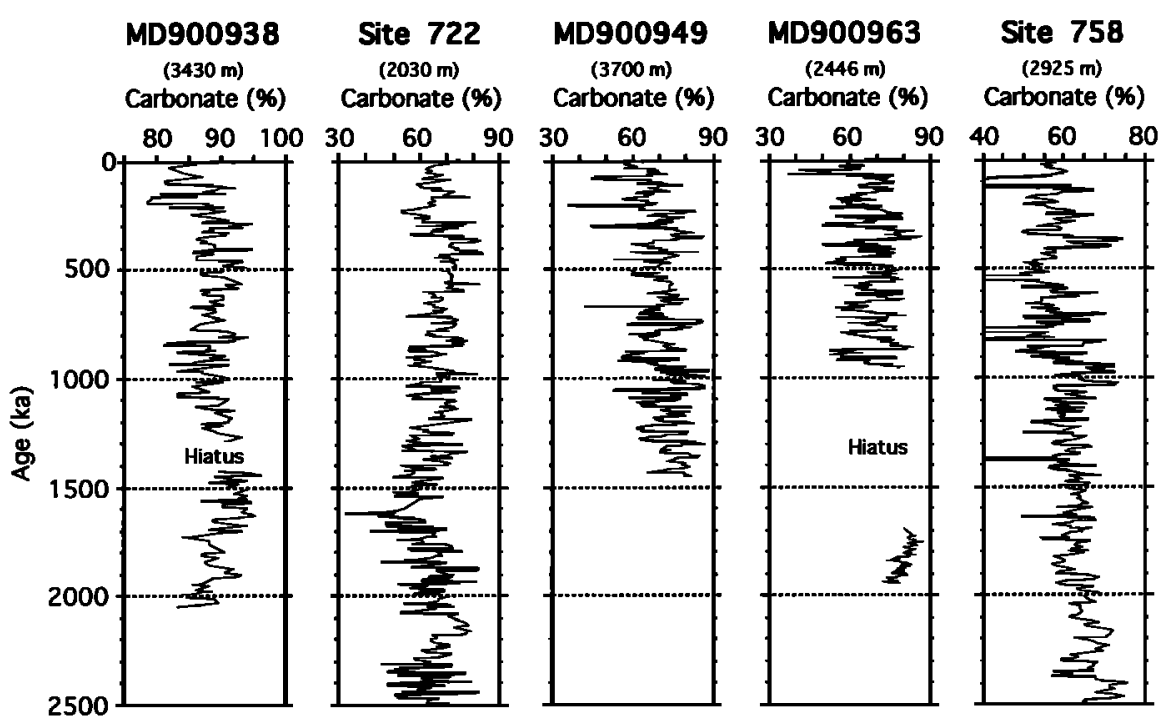

Figure 3. Plots of carbonate contents versus age for cores MD900938 and MD900940 (Madingley Rise, western equatorial Indian Ocean), cores MD900949 and MD900963 (Maldives area, central equatorial Indian Ocean), and sites 722 (Owen Ridge, Arabian Sea) and 758 (Ninetyeast Ridge, eastem equatorial Indian Ocean). Carbonate contents data from sites 722 and 758 are from Murray and Prell [1991] and Farrell and Janecek [1991], respectively. 


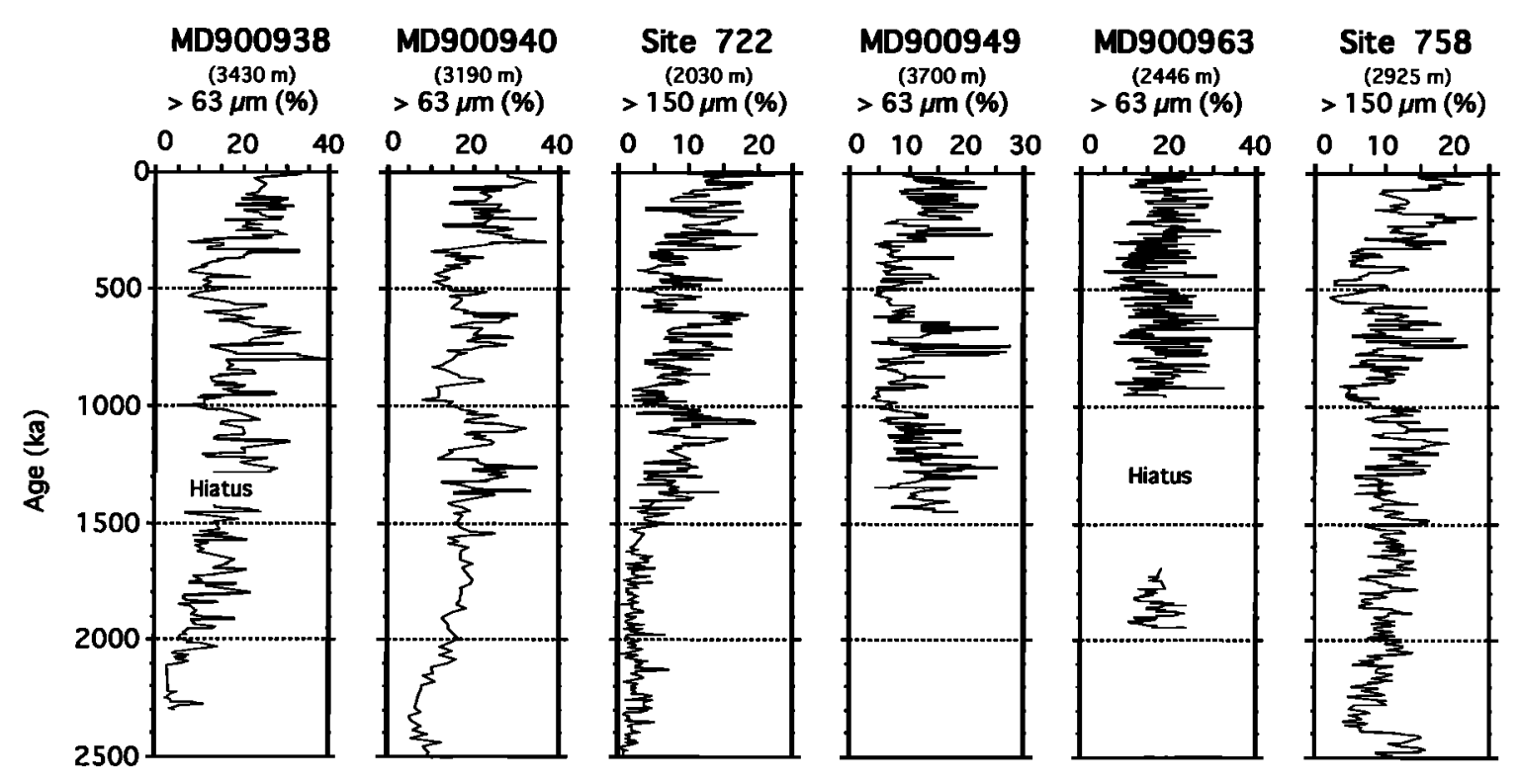

Figure 4. Plots of coarse fraction contents versus age for cores MD900938 and MD900940 (Madingley Rise, western equatorial Indian Ocean), cores MD900949 and MD900963 (Maldives area, central equatorial Indian Ocean), and sites 722 (Owen Ridge, Arabian Sea) and 758 (Ninetyeast Ridge, eastern equatorial Indian Ocean). Coarse fraction data from sites 722 and 758 are from Murray and Prell [1991] and Farrell and Janecek [1991], respectively.

index (measured in the 250 - to $355-\mu \mathrm{m}$ fraction) and the index measured in the $>150-\mu \mathrm{m}$ fraction (Figure 5 ) indicates that our preservation index is a valuable tool for estimating carbonate preservation/dissolution despite the smaller size range of the 250 - to $355-\mu \mathrm{m}$ fraction and the relatively low number of fragments it contains compared to the $>150-\mu \mathrm{m}$ fraction.
A good relationship can be seen in Figures 6 and 7 between coarse fraction content and foraminiferal preservation in cores MD900938, MD900949, and MD900963 (despite the fact that the sampling resolution of the foraminiferal fragmentation analyses in cores MD900938 and MD900949 is lower than the sampling resolution of the grain size analyses). This
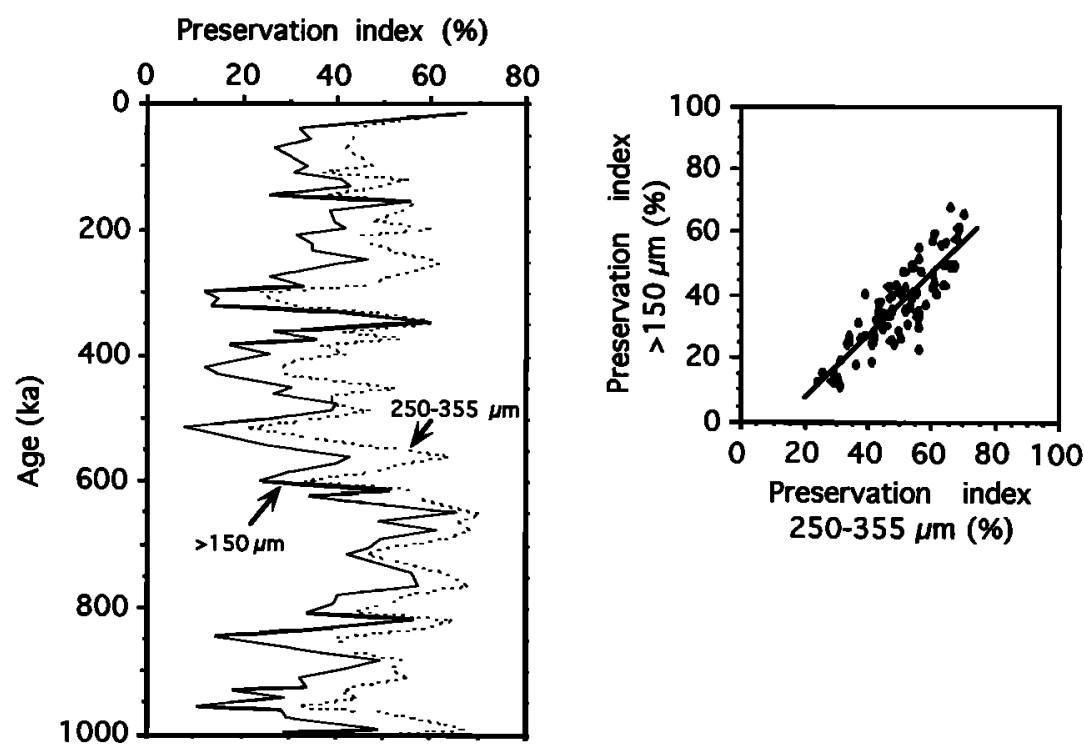

Figure 5. (left) Plots of carbonate preservation indices versus age for core MD900938 over the last 1000 kyr. Whole foraminifera/whole foraminifera plus foraminiferal fragments, in percentages, measured in the 250 to $355-\mu \mathrm{m}$ size fraction (dashed line) and the $>150-\mu \mathrm{m}$ size fraction (solid line). (right) Plot of the $>150-\mu \mathrm{m}$ preservation index (PI) versus the 250 - to $355-\mu \mathrm{m}$ index. In the samples studied there appears to be a strong linear correlation between the two indices. $\mathrm{PI}_{150}=\left(1.01 \times \mathrm{PI}_{250-355}\right)-13.7\left(\mathrm{R}^{2}=0.74\right)$. 


\section{MD900938}

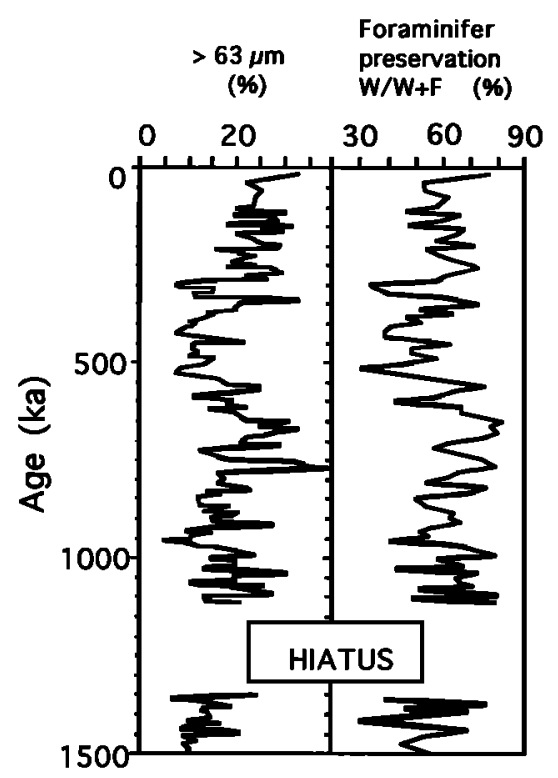

MD900949



MD900963

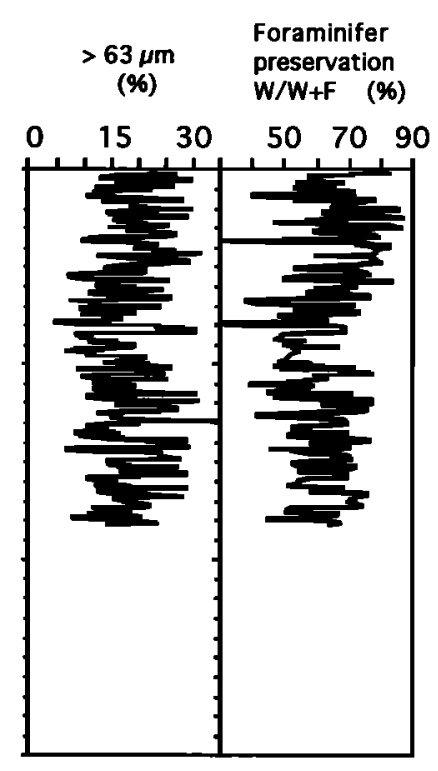

Figure 6. Coarse fraction content $(>63 \mu \mathrm{m})$ and foraminiferal preservation index (calculated as the percentage of whole foraminifera (W) to fragments plus whole foraminifera (W+F)) for SEYMAMA cores MD900938, MD900949, and MD900963. The good visual correlation between the two curves suggests that most of the changes in grain size, and especially the long-term oscillations observed in Figure 4, are controlled by carbonate dissolution.

relationship is particularly clear in the two shallowest cores MD900938 (3430 m) and MD900963 (2446 m). Because dissolution becomes a more dominant sedimentary process as water depth increases, we expected to find the strongest relationship between foraminiferal fragmentation and coarse fraction content in core MD900949, which is the deepest SEYMAMA section studied $(3700 \mathrm{~m})$. Surprisingly, the correlation is less obvious in this core, although it is still noticeable. The following scenario could well explain such results: In the early stages of dissolution (little loss of carbonate and shallow water depths), foraminiferal fragmentation results in a net transfer of material from the coarse to the fine fractions, whereas there is only a little loss of the finest particles through total dissolution. Thus grain size changes and foraminiferal fragmentation are strongly related. With increasing water depth, as loss of carbonate becomes more important, grain size distribution results from two processes that act in opposite directions: foraminiferal fragmentation tends to enrich the finest size fractions relative to the coarser ones, whereas at the same time, increased dissolution of the finest particles tends to reduce significantly the relative contribution of the fine fraction to the total sediment. This significant loss of the finest fraction may well explain the loose relationship between foraminiferal fragmentation and the coarse fraction content at great depths.

The intersite comparison between the different coarse fraction curves (Figure 4) clearly shows that the same longterm signal is recorded whatever the coarse size fraction ( $>63$ $\mu \mathrm{m}$ in SEYMAMA cores and $>150 \mu \mathrm{m}$ in ODP sites). In core MD900938, we studied the relative weight contributions of the $>63-\mu \mathrm{m},>250-\mu \mathrm{m}$, and $>355-\mu \mathrm{m}$ fractions to the total sediment. Our data confirm that changes in grain size composition mainly result from variations in the relative importance of the finest and coarsest end-members $(<63 \mu \mathrm{m}$ and $>355 \mu \mathrm{m}$ ), whereas the relative abundances of intermediate fractions $(63-250 \mu \mathrm{m}$ and $250-355 \mu \mathrm{m})$ show little change (Figure 8). Thus grain size changes controlled by carbonate dissolution imply a net transfer of foraminiferal fragments from the coarsest fractions to the finest ones. In the intermediate fractions, as suggested by Berger et al. [1982], weight losses due to the transfer of small fragments to the finer fractions were almost balanced by gains due to large fragments coming from the coarser fractions. Thus when dissolution increases, the number of fragments in intermediate fractions increases, although the weight contribution of these fractions to the total sediment does not change significantly.

Records from core MD900938, and more particularly from core MD900963, show that not only the long-term oscillation but also the higher-frequency fluctuations in coarse fraction content are mimicked by the preservation index (Figures 6 and 7). The high-resolution age models developed at sites 722 and 758 allow us to test if the higher-frequency fluctuations in coarse fraction records are correlatable among these sites.

Over the last $1000 \mathrm{kyr}$, the two coarse fraction curves bear a strong resemblance when plotted versus age (Figure 9 (middle)). Not only the large-scale fluctuations but also most of the smaller-scale changes (occurring at glacial-interglacial and higher frequencies) are correlatable among these two remote sites. Before about $1000 \mathrm{ka}$, however, correlations are usually poorer, with intervals where the grain size signals appear almost anticorrelated (see below for discussion). We have no detailed foraminiferal fragmentation records for sites 


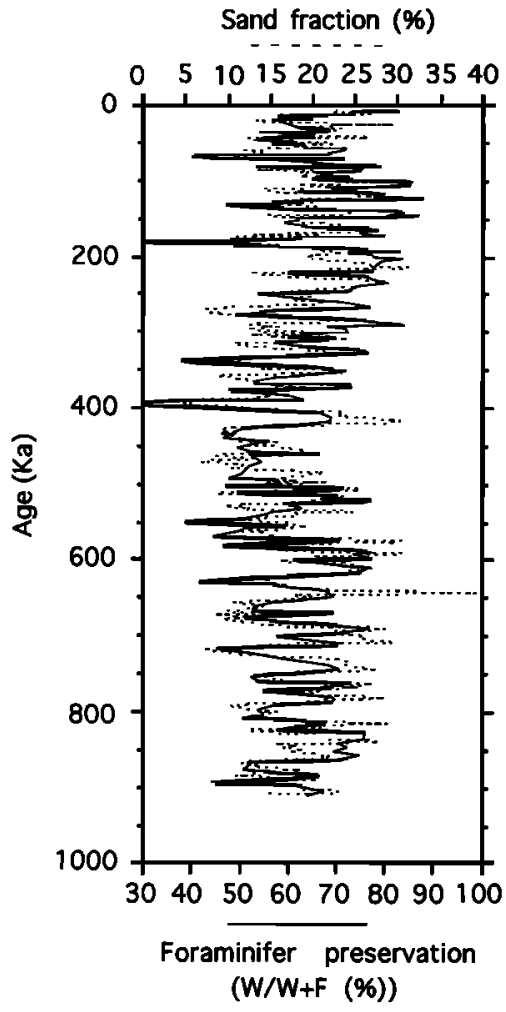

Figure 7. Superimposition of coarse fraction content (> 63 $\mu \mathrm{m})$ and preservation index measured in core MD900963 shows that not only the long-term oscillation (see also Figures 4 and 6) but also the high-frequency changes in the coarse fraction record are controlled by changes in carbonate dissolution/preservation.

722 and 758. Nevertheless, a positive relationship has been observed between coarse fraction content and foraminiferal preservation at site 758 [Chen and Farrell, 1991] and in piston core RC27-61 retrieved in the vicinity of site 722 (Murray and Prell, 1992). Furthermore, sites 722 and 758 lie in very different environments, some $3700 \mathrm{~km}$ apart (Figure 1 and Table 1); thus it is unlikely that changes in surface productivity, dilution by nonbiogenic material, or winnowing at the seafloor could explain such an impressive, long-distance correlation of coarse fraction records over the last $1000 \mathrm{kyr}$. As concluded for the long-term oscillation, these regionally correlatable "high-frequency" changes in grain size are most probably controlled by carbonate dissolution pulses. In the late Pleistocene, the coarse fraction changes are consistent with the "classical" Indo-Pacific dissolution pattern [Berger, 1973; Volat et al., 1980; Vincent, 1985], showing increased carbonate dissolution (coarse fraction minima) during interglacial intervals and enhanced carbonate preservation (coarse fraction maxima) during glacial intervals (Figure 9). However, the dissolution/preservation pattern is not a simple glacial-interglacial dichotomy. In many intervals, the coarse fraction cycles appear slightly shifted with respect to the glacial-interglacial cycles, in agreement with observations made in deep-sea carbonate records [e.g., Luz and Shackleton, 1975; Moore et al., 1977; Peterson and Prell, 1985a; Farrell and Prell, 1989].

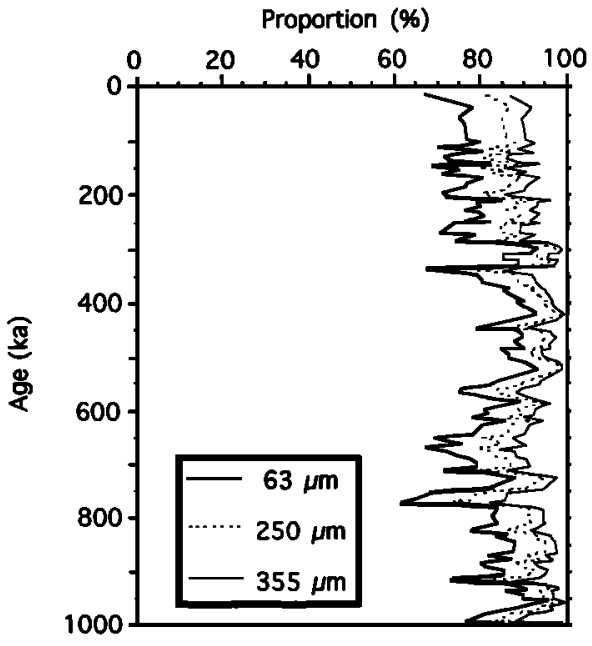

Figure 8. Abundance distribution of size classes as a function of age in core MD900938. We measured the weight percent of the $>63-\mu \mathrm{m}$ fraction (thick solid line), we subsieved this sand fraction to measure the weight percent of the $>250$ $\mu \mathrm{m}$ fraction (dashed line), and finally we measured the weight contribution of the $>355-\mu \mathrm{m}$ fraction by subsieving the $>$ $250-\mu \mathrm{m}$ fraction (thin solid line).

As noted above, although the correlation between coarse fraction records of sites 722 and 758 is fairly good, there are noticeable differences in these records. These discrepancies are especially noteworthy in the early Pleistocene. Between about $1100 \mathrm{ka}$ and $1250 \mathrm{ka}$, for instance, the two grain size curves appear almost completely anticorrelated (Figure 9, (middle)). Prior to about $900 \mathrm{ka}$, the lack of large-amplitude 100-kyr glacial-interglacial oscillations in carbonate dissolution (which dominate the grain size records of sites 722 and 758 in the late Pleistocene) may explain why small-amplitude, local grain size changes are able to perturb more efficiently the regional (global) signal. Also, in the early Pleistocene, we cannot rule out the possibility that discrepancies between grain size records may result from inaccuracies in our age models, which rest upon the intersite correlation of lowamplitude $41-\mathrm{kyr} \delta^{18} \mathrm{O}$ cycles. In the late Pleistocene, however, there is little doubt concerning the accuracy of the $\delta^{18} \mathrm{O}$ stratigraphy. Consequently, minor discrepancies between the coarse fraction records from sites 722 and 758 can be confidently ascribed to the superimposition of local signals (e.g., winnowing and productivity) on the regionally correlatable dissolution signal.

Unlike grain size records, carbonate contents of sites 722 and 758 cannot be readily correlated (Figure 3 ). Variations in carbonate content at site 758 (2925-m water depth) primarily reflect changes in surface productivity and terrigeneous input [Farrell and Janecek, 1991], whereas those at site 722 mainly reflect dilution by terrigeneous material and do not reflect dissolution; for example, low $\mathrm{CaCO}_{3}$ content observed in glacial intervals is associated with a good preservation of foraminiferal tests [Murray and Prell, 1991, 1992]. In some areas, carbonate content is a good proxy for carbonate dissolution and can be used for long-distance intersite correlations [e.g., Hays et al., 1969]. However, our 


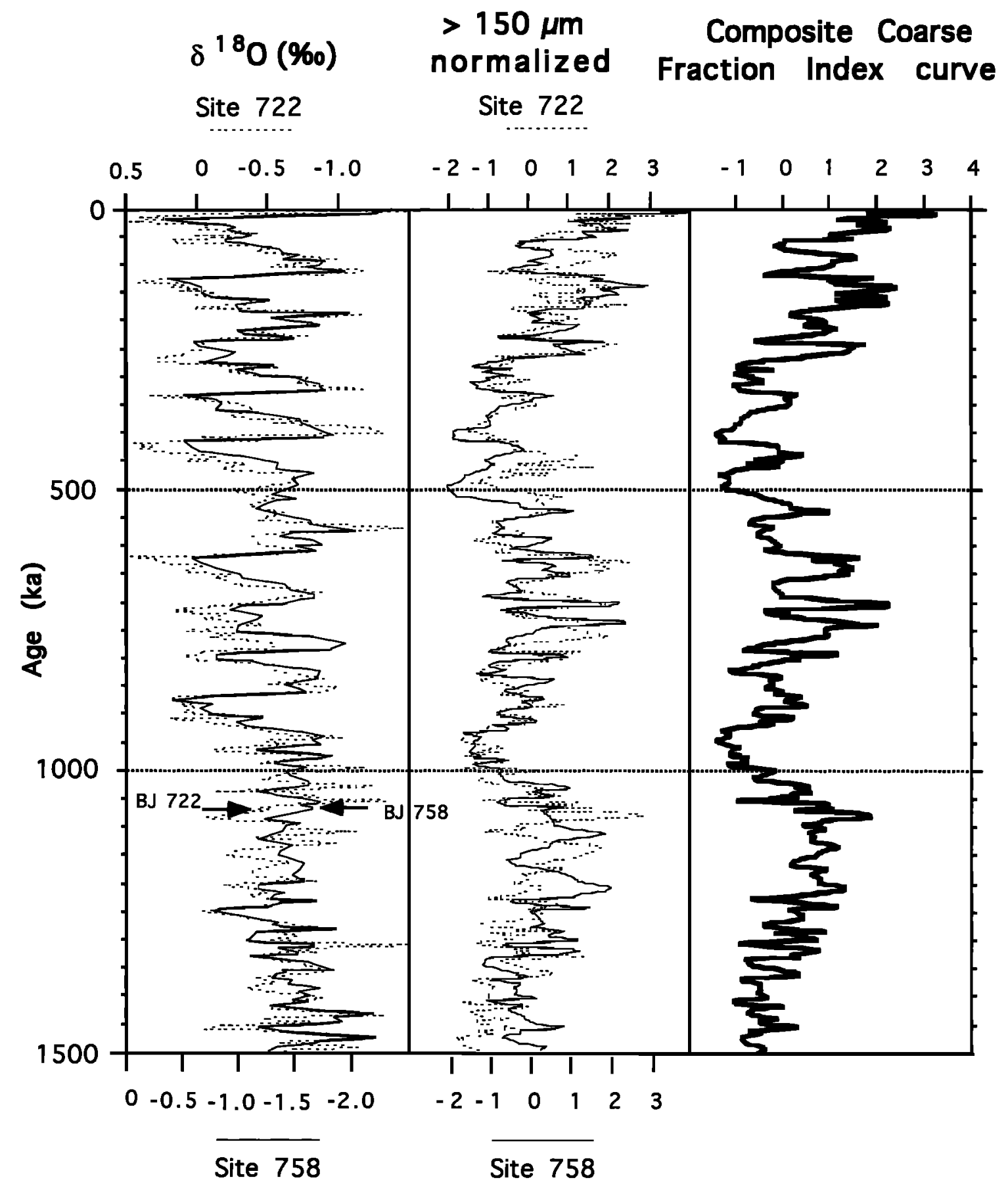

Figure 9. (left) Detailed $\delta^{18} \mathrm{O}$ records from sites 722 and 758 [Murray and Prell, 1991; Farrell and Janecek, 1991]. These isotopic records were independently correlated to the orbitally tuned isotopic record from ODP site 677 [Shackleton et al., 1990]. This age model allows a detailed comparison between coarse fraction records from both sites. (middle) Normalized coarse fraction records from sites 722 and 758 . The very good match suggests that not only the long-term oscillation (see also Figures 4 and 6) but also most of the higherfrequency fluctuations are correlatable from the Owen Ridge (Arabian Sea, site 722) to the Ninetyeast Ridge (eastern equatorial Indian Ocean, site 758), some $3700 \mathrm{~km}$ away. (right) Composite Coarse Fraction Index curve (CCFI) obtained by stacking the normalized coarse fraction records. This method tends to diminish local signals and enhance regionally correlatable signals. 
observations confirm that it is not always true. In the tropical Indian Ocean, coarse fraction content constitutes a better tool for intersite correlations and appears to be a much more sensitive indicator of dissolution than carbonate content in relatively shallow sites (above the lysocline).

The same carbonate dissolution pattern is observed during the Pleistocene in the Indian Ocean and the Pacific Ocean, with increased carbonate dissolution during interglacial intervals and enhanced carbonate preservation during glacial intervals [e.g., Volat et al., 1980; Vincent, 1985]. Therefore, some interoceanic correlations between coarse fraction records should be possible if global signals have not been masked by local or regional processes. To test the possibility of interoceanic correlations, we selected the Deep Sea Drilling Project (DSDP) site 572 (central equatorial Pacific) in which a good quality coarse fraction record $(>150 \mu \mathrm{m})$ and a detailed $\delta^{18} \mathrm{O}$ curve are available [Farrell, 1991]. We developed an age model at site 572 by aligning features of the $\delta^{18} \mathrm{O}$ record with the features in the orbitally tuned $\delta^{18} \mathrm{O}$ record from site 677
[Shackleton et al., 1990]. In Figure 10, the coarse fraction records from sites 572, 722, and 758 are plotted versus age for comparison. At every site, coarse fraction contents generally increase during glacial intervals and decrease during interglacial intervals. These fluctuations, which we interpret as reflecting changes in carbonate dissolution, are in agreement with the Indo-Pacific dissolution-preservation history observed in deep-sea carbonate content records [Berger, 1973; Vincent, 1985; Farrell and Prell, 1989]. As was already noted for sites 722 and 758 (see above), in numerous places the coarse fraction cycles in site $\mathbf{5 7 2}$ appear slightly shifted with respect to the glacial-interglacial cycles: preservation maxima (peaks in the coarse fraction curve) are centered on the intervals of most rapid deglaciation rather than at the glacial maxima (e.g., coarse fraction peaks at about 330 and $420 \mathrm{ka}$ ). Berger and Vincent [1981] have reported such preservation spikes coinciding with deglaciation, in calcareous microfossil assemblages from piston cores of the equatorial Pacific. The preservation spike corresponding to the last deglaciation is

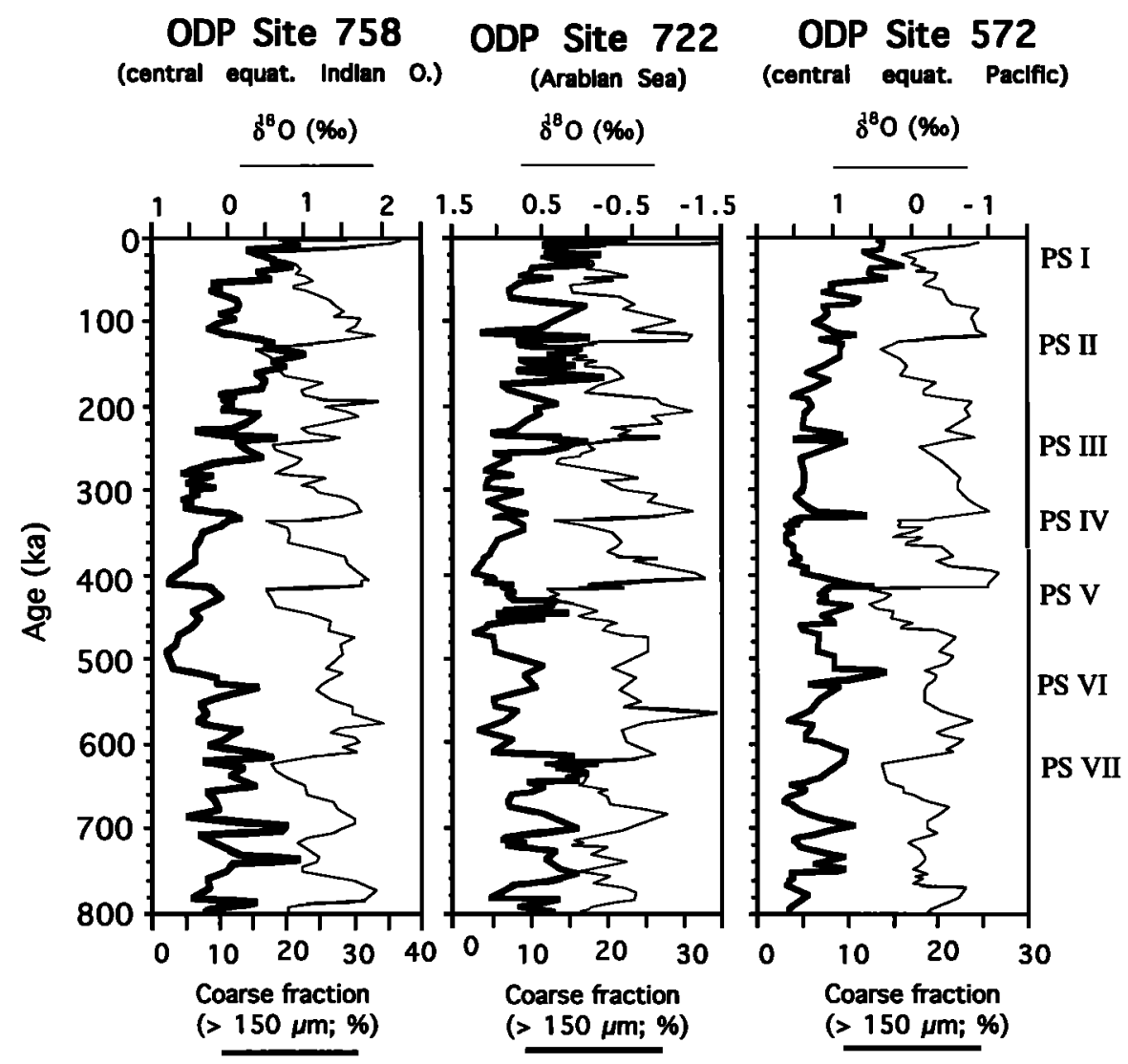

Figure 10. Coarse fraction contents and $\delta^{18} \mathrm{O}$ values plotted versus age at ODP sites 758 and 722 (tropical Indian Ocean) and 572 (equatorial Pacific) for the last $800 \mathrm{kyr}$ (data from Farrell and Janecek [1991], Murray and Prell [1991], Farrell [1991], respectively). At all three sites, coarse fractions generally increase during glacial intervals and decrease during interglacial intervals. We interpret this pattern in terms of carbonate dissolution (e.g., increased dissolution during interglacial reduces coarse fraction content through fragmentation of foraminifera). Preservation spikes (PS I, PS II, etc.) at right are those noted in piston cores of the equatorial Pacific by Berger and Vincent [1981]. Many of these preservation spikes are clearly visible here in the three coarse fraction records and, as already noted by Berger and Vincent, coincide with deglaciation events. 
considered to be a global phenomenon [Berger, 1977], although François et al. [1990] recently suggested that this preservation spike is limited to the Atlantic Ocean.

\section{Construction of a Composite Coarse Fraction Index Curve for the Tropical Indian Ocean}

Coarse fraction records from sites 722 and 758 were normalized and linearly interpolated at a regular 2-kyr time interval (Figure 9 (middle)). We stacked these normalized coarse fraction curves to produce a reference coarse fraction record in which local signals tend to cancel out. The resulting Composite Coarse Fraction Index curve (CCFI) is shown in Figure 9 (right) and the values are given in Appendix Table $A{ }^{1}$. (The CCFI used in this paper corresponds to the Composite Grain Size Index (CGSI) used in previously published studies [Bassinot, 1993a, b; Bassinot et al., 1992]. Although this terminology change may introduce some confusion, it is more proper to use the term "coarse fraction" (rather than "grain size") to refer to one distinct size fraction obtained by wet sieving).

Peterson and Prell [1985a] have provided a 800-kyr record of bathymetric and temporal variations of carbonate preservation in the equatorial Indian Ocean. They used a quantitatively defined Composite Dissolution Index (CDI) measured on a set of 7 piston cores retrieved from water depths of $2900 \mathrm{~m}$ to $4400 \mathrm{~m}$ on the Ninetyeast Ridge near $6^{\circ} \mathrm{S}$. Core V34-53 was given special attention because of its sensitive location ( 3812 m) near the depth of the present-day foraminiferal and hydrographic lysoclines in the equatorial Indian Ocean (3800 $\mathrm{m})$. For intercomparison between our CCFI curve and the CDI curve from core V34-53, we had to modify the initial age model developed by Peterson and Prell [1985a]. This age model rested upon the correlation of the $\delta^{18} \mathrm{O}$ record from core V34-53 to the SPECMAP stack [Imbrie et al., 1984]. The orbital chronology developed from site 677 introduces three additional precessional cycles in isotopic stages 17 and 18 compared to the SPECMAP solution [Shackleton et al., 1990]. The new age model for core V34-53 was developed by correlating the $\delta^{18} \mathrm{O}$ record of core V34-53 (data from Peterson and Prell [1985a]) to the orbitally tuned $\delta^{18} \mathrm{O}$ record from site 677 [Shackleton et al., 1990] using the program "LINAGE".

There is a generally excellent match between our CCFI curve and the CDI curve from core V34-53 [Peterson and Prell, 1985a] (Figure 11). Over the interval from about $350 \mathrm{ka}$ to 600 $\mathrm{ka}$, however, low accumulation rates (around $0.5 \mathrm{~cm} \mathrm{kyr}^{-1}$ ) due to intensified dissolution and loss of dissolved carbonate from the sediments tend to smooth the isotopic record from core V34-53. This smoothed part of the $\delta^{18} \mathrm{O}$ record is difficult to correlate confidently to the $\delta^{18} \mathrm{O}$ curve from site 677 , which probably explains slight discrepancies (leads/lags) between the CCFI and the CDI records.

Despite these slight discrepancies, the generally good agreement between the CCFI curve and the CDI curve clearly indicates that the CCFI provides a reliable though qualitative record of past changes in carbonate dissolution in the tropical

\footnotetext{
'Appendix Table Al Is available with entire article on microfiche. Order from the American Geophysical Union, 2000 Florida Avenue, N.W., Washington, D.C. 20009. Document P94-001; \$2.50. Payment must accompany order.
}

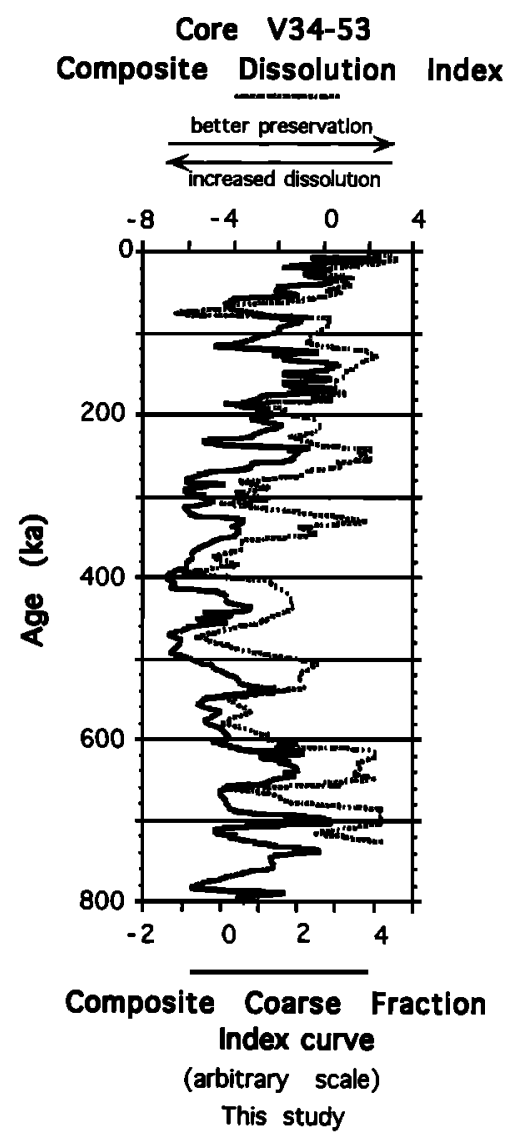

Figure 11. Comparison of the Composite Coarse Fraction Index curve (CCFI) (this study) with the Composite Dissolution Index curve from core V34-53 (Ninetyeast Ridge) [Peterson and Prell, 1985a). The impressive match between the two curves demonstrates unambiguously that coarse fraction changes that are correlatable over long distances in the tropical Indian Ocean are controlled by regional (or global) changes in carbonate dissolution. The CCFI curve may be used as a reference curve to develop a "coarse fraction stratigraphy" for the last $1500 \mathrm{kyr}$.

Indian Ocean. It also extends back in time (to $1500 \mathrm{ka}$ ) the record of dissolution first provided by the CDI record. Additional high-resolution coarse fraction records are necessary to test the reliability of the CCFI curve over the interval from 900 to $1500 \mathrm{ka}$. However, over this time interval, the CCFI curve seems to provide a good reference for the long-term oscillation.

In deep-sea carbonate deposits, changes in $P$ wave velocity parallel changes in coarse fraction content [e.g., Johnson et al., 1977; Hamilton et al., 1982]. Therefore, in the tropical Indian Ocean, $\boldsymbol{P}$ wave velocity profiles can be tied to a precise stratigraphic and chronostratigraphic framework by correlating them to the CCFI curve [Bassinot, 1993a, b; Bassinot et al., 1992]. Because of the potential for nearcontinuous measurements of acoustic velocity on unsplit cores, "sonostratigraphy" may become a rapid means of determining the stratigraphic position of core samples and of getting some indication of paleoceanographic conditions that prevailed during sediment deposition [Bassinot, 1993a, b; Bassinot et al., 1992]. 


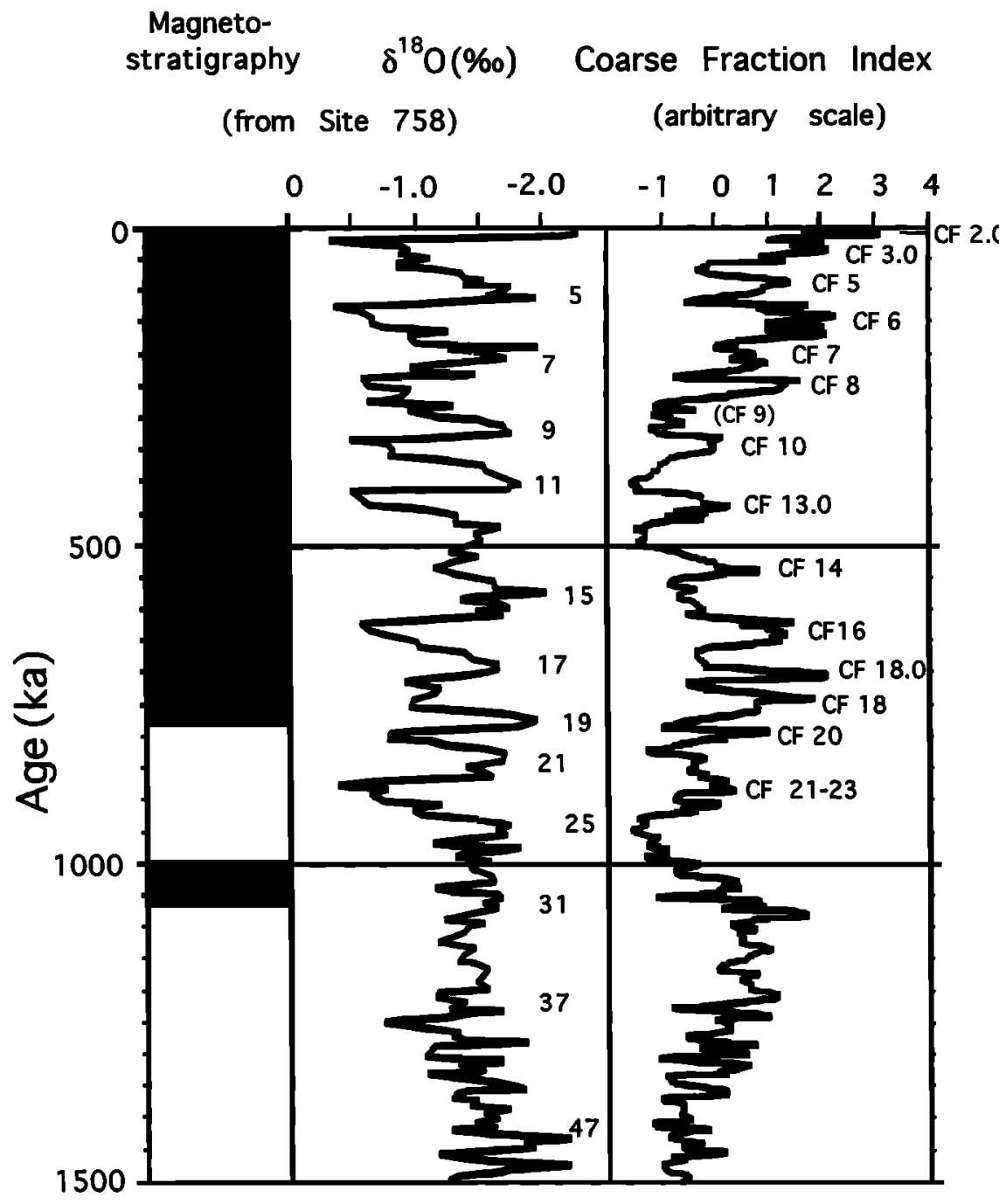

Figure 12. Composite Coarse Fraction Index curve (CCFI) tied into a precise stratigraphic framework using the magnetostratigraphy and isotope stratigraphy of site 758. Major peaks of the CCFI curve have been labeled according to their position relative to the $\delta^{18} \mathrm{O}$ stratigraphy (see text for details).

In Figure 12, the CCFI curve is shown with the oxygen isotope stratigraphy and the magnetostratigraphy from site 758. In the 0-900 $\mathrm{ka}$ interval, we have assigned numbers to major CCFI peaks (i.e., preservation events) based on their respective positions relative to the $\delta^{18} \mathrm{O}$ stratigraphy. Peaks were labeled "CF" followed by the oxygen isotopic stage number in which they reach their maximum. Higher CCFI values are generally observed in glacial intervals (e.g., peaks CF6, CF8, CF10, CF14, and CF16) or are shifted toward early stages of deglaciation (e.g., CF18.0). Nevertheless, peaks also appear in some interglacial intervals (e.g., CF5 and CF7). These latter preservation peaks, which generally have lower maximum values than peaks in adjacent glacial intervals, are bracketed by sharp dissolution events. For instance, the peak CF5, which reaches lower values than peaks CF3.0 and CF6, is bracketed by the important dissolution event that occurs at the transition between oxygen isotope stage 5 and 4 (a global event which has been recognized in the Indo-Pacific Ocean as well as in the Atlantic Ocean [Crowley, 1985]) and a dissolution event occurring in substage 5.5. In the CCFI record, both dissolution events have roughly the same magnitude, whereas in the CDI record, the dissolution event at the stage 4/5 transition is much more clearly expressed (Figure 11).

\section{Spectral Analysis of the Composite Coarse Fraction Index Record}

We analyzed the CCFI variability in the frequency domain over the last $900 \mathrm{kyr}$ using the Blackman-Tukey approach with $50 \%$ lags [Jenkins and Watts, 1968]. Much of the total variance in the CCFI record (Figure 13, solid line) occurs in the low-frequency end of the spectrum and is associated with the long-term oscillation. Observations in the time domain over the last $1500 \mathrm{kyr}$ suggest that the long-term oscillation has an irregular cycle length of the order of $\sim 500 \mathrm{kyr}$ (Figures 9 and 14). Minima in the CCFI curve (maxima of dissolution) are found approximately at $400 \mathrm{ka}, 950 \mathrm{ka}$, and $1400 \mathrm{ka}$, and maxima are found at about $150 \mathrm{ka}, 700 \mathrm{ka}$, and $1125 \mathrm{ka}$ 


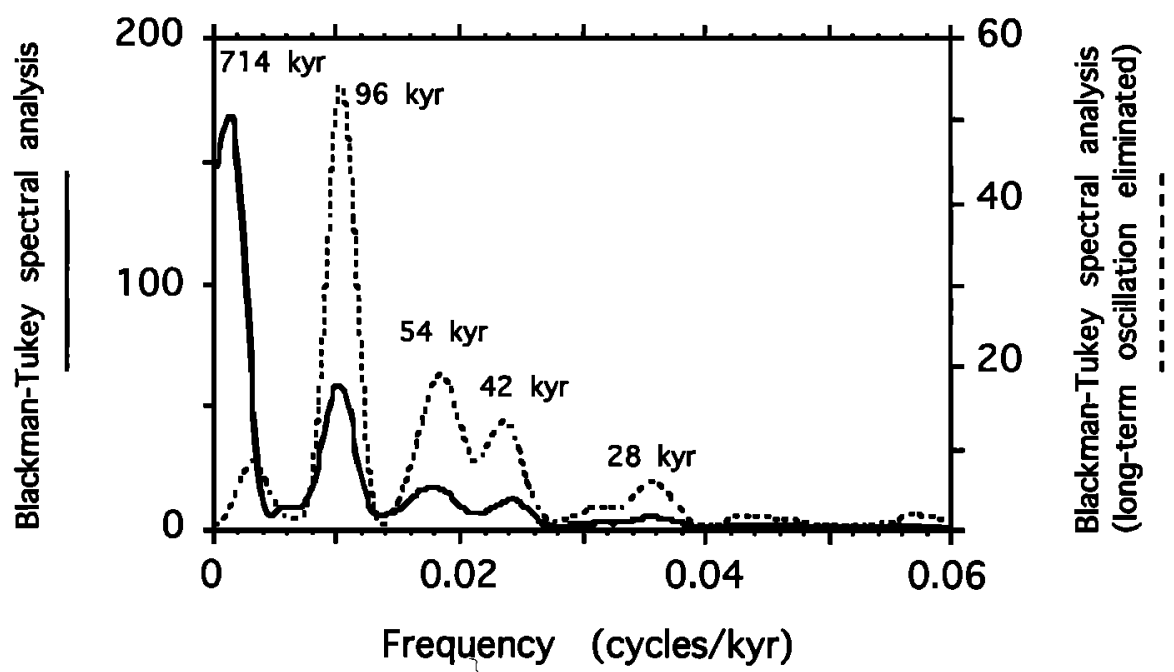

Figure 13. Blackman-Tukey spectral analysis of the Composite Coarse Fraction Index curve (CCFI) over the last 900 kyr. Dashed line indicates the power spectrum calculated after the long-term oscillation of the CCFI record has been eliminated to resolve more accurately the high-frequency cycles (see text for details).

\section{Composite Coarse Fraction Index (arbitrary scale)}

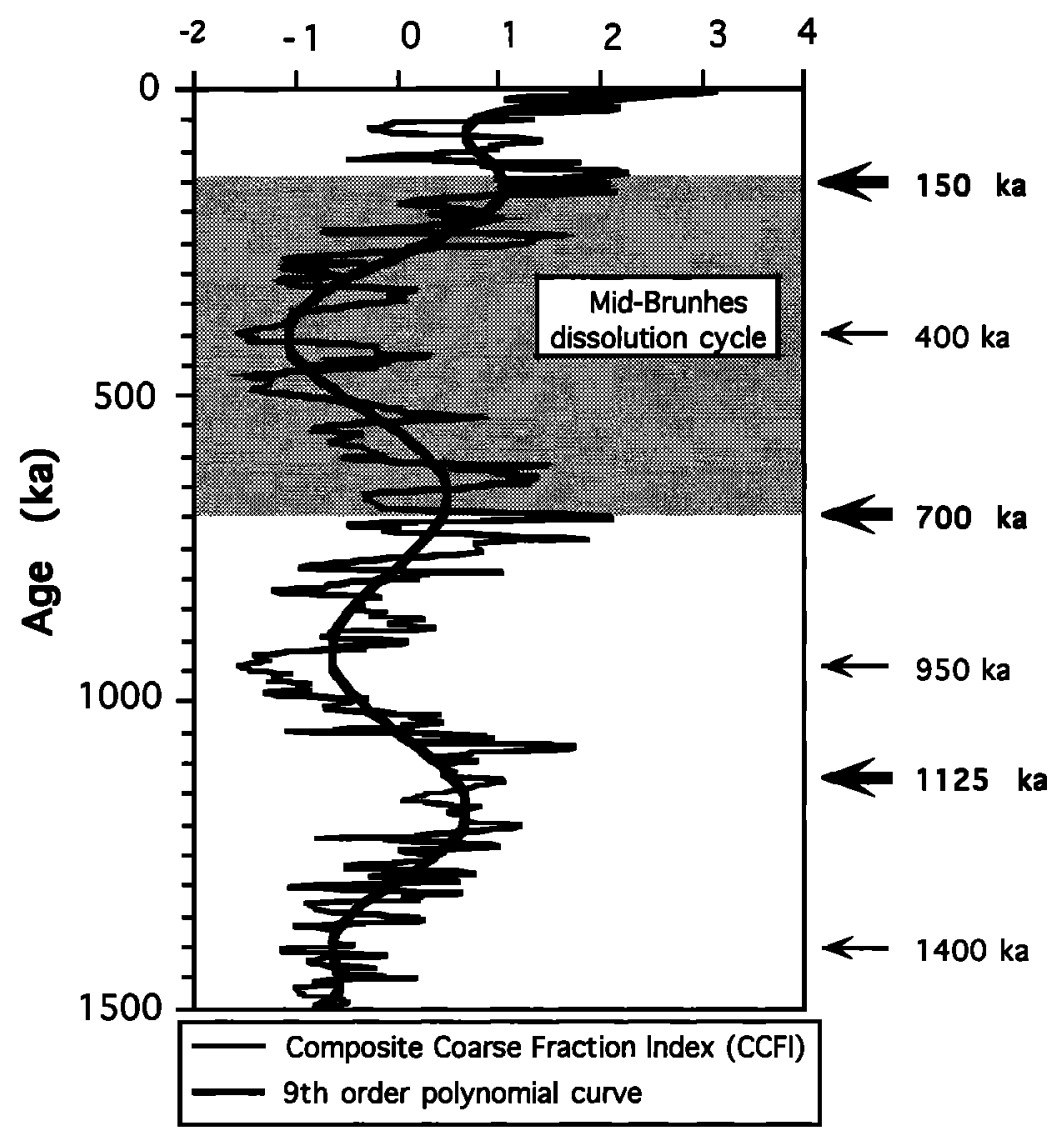

Figure 14. Composite Coarse Fraction Index curve smoothed with a 30-point window running average to enhance the long-term dissolution oscillation that has an irregular wavelength of the order of $\sim 500 \mathrm{kyr}$. Thin and thick arrows indicate dissolution maxima and minima, respectively. 
(Figures 9 and 14). Although the long-term oscillation in the CCFI record has an irregular wavelength, we will refer to it as the "-500-kyr oscillation" for convenience.

In series dominated by high-amplitude low-frequency oscillations, the high-frequency part of the power spectra is distorted by variance transfer from the low-frequency peaks. Prewhitening techniques are commonly used to reduce this distortion [Jenkins and Watts, 1968]. However, in the CCFI power spectrum, we noticed that prewhitening not only reduced the amplitude of the $-500-\mathrm{kyr}$ cycle but also significantly reduced the power estimate of the $\sim 100-\mathrm{kyr}$ oscillation. In order to define better the high-frequency oscillations without disturbing the amplitude ratios between the primary Milankovitch bands, we decided to eliminate long-term oscillations by fitting a polynomial curve to the CCFI record and then subtracting this curve from the bulk record. An order of 9 polynomial curve satisfactorily described the long-term oscillation (Figure 14).

In the resulting detrended CCFI record, variance clearly occurs in the eccentricity (96 kyr) and obliquity (42 kyr) frequency bands, but the absence of discrete spectral peaks at 23 and $19 \mathrm{kyr}$ (Figure 13, dashed line) suggests that the CCFI curve does not record a precessional response. The lack of a precession signal in the CCFI record may be due either to the attenuation of the high-frequency signals during the stacking procedure or to the true absence of precession signals in the records of coarse fraction variations.

\section{Spectral Analyses of the Coarse Fraction Records From Sites 722 and 758}

We eliminated the long-term oscillation from the individual coarse fraction records of sites 722 and 758 using the same technique used for the CCFI record (see above), and we performed Blackman-Tukey spectral analyses (Figure 15). Strong 98-kyr cycles in the coarse fraction records of sites 722 and 758 reflect fluctuations associated with late Pleistocene glacial-interglacial changes, as evidenced by the comparison of $\delta^{18} \mathrm{O}$ and coarse fraction records in the time domain (Figure 9). Variance is also clearly found in the obliquity band (41 kyr) at site 758 but is weaker at site 722 . Power spectra of coarse fraction records also display frequencies that are not associated with the primary Milankovitch bands (Figure 15) $(27,32$, and $60 \mathrm{kyr}$ for site 722 and $\sim 30$ and $53 \mathrm{kyr}$ for site 758). These periods are close to those of 29,35 , and $54 \mathrm{kyr}$ found in lowlatitude deep-sea records of past climatic changes (e.g., eolian grain size records in the Pacific, sea surface temperature (SST) in the southern tropical Indian Ocean, and indices of monsoon strength [Pisias and Rea, 1988; Clemens and Prell, 1991a, b; Murray and Prell, 1991]). These periods may be related to a nonlinear response of the low-latitude climatic system to insolation forcing at the primary Milankovitch bands [Clemens and Prell, 1991a, b].

The $\delta^{18} \mathrm{O}$ and coarse fraction records at site 758 show a small peak at a period of about $23 \mathrm{kyr}$ (Figure 15). At site 722, no precession-related peaks were observed in the power spectrum of the coarse fraction record although a 23-kyr cycle is observed in the power spectrum of the $\delta^{18} \mathrm{O}$ record, indicating that the sequence probably permits the recovery of a precession signal when it exists (Figure 15). Thus, given these data, and as concluded earlier by Peterson and Prell [1985a], it seems that there are no clear regional precession-related oscillations in the carbonate dissolution pattern from the tropical Indian Ocean. Based on the weak linkage of the CDI curve and the $\delta^{18} \mathrm{O}$ record from core V34-53 over the precessional frequencies, and the high coherencies at the 100 $\mathrm{kyr}^{-1}$ and 41-kyr ${ }^{-1}$ frequencies, Peterson and Prell [1985a] suggested that deepwater circulation changes, driven by highlatitude climatic forcing in the north Atlantic, were the principal source of variability in the preservation record of the equatorial Indian Ocean.

However, additional high-resolution data on Ninetyeast Ridge and Owen Ridge are necessary to check our results. Based on the sedimentation rates and sampling intervals, the lowest sampling resolution encountered should be about $10 \mathrm{kyr}$ for both sites 722 and 758 (mean sampling intervals over the last $900 \mathrm{kyr}$ are 5.5 and $6.5 \mathrm{kyr}$ for sites 722 and 758 , respectively). Theoretically, a sampling interval of $10 \mathrm{kyr}$ is just high enough to resolve a 20-kyr cycle (the spectral estimates covering a frequency range up to the Nyquist frequency of 0.05 cycles $\mathrm{kyr}^{-1}$ ). However, relatively low sedimentation rates at sites 722 and 758 (i.e., at site 758 , sedimentation rates range roughly from 1.2 to $2.5 \mathrm{~cm} \mathrm{kyr}{ }^{-1}$, with a mean value of $1.8 \mathrm{~cm} \mathrm{kyr}^{-1}$ ) most probably result in a significant reduction in the variance at high frequencies, as predicted by bioturbation models [i.e., Pisias, 1983].

\section{High-Resolution 900-kyr Record From Core MD900963 (Maldives Area): Dissolution Changes Associated With the Decay of Organic Carbon}

Core MD900963 offers the best opportunity to look at high-frequency signals. Although core MD900963 does not extend into the lower Pleistocene, the youngest part of the long-term dissolution cycle ("mid-Brunhes dissolution event") is clearly observed in the coarse fraction and the foraminiferal preservation records (e.g., Figures 4, 6, and 7), with maximum dissolution centered at about $400 \mathrm{ka}$. On shorter scales, however, the record from core MD900963 differs markedly from what we observed at sites 722 and 758 . Although many dissolution-preservation events can be correlated between the CCFI curve and the coarse fraction record from core MD900963 (arrows on Figure 16), the coarse fraction curve from core MD900963 appears to be clearly dominated by higherfrequency changes than coarse fraction records from sites $\mathbf{7 2 2}$ and 758. The strong correlation between the coarse fraction record and the preservation index curve in core MD900963 (Figure 7) again indicates that these high-frequency grain size changes are also primarily controlled by carbonate dissolution. Spectral analysis of the foraminiferal preservation record shows that beside the large amount of variance associated with the long-term oscillation, much of the variability occurs at the periods associated with precession (23 and $19 \mathrm{kyr}$ ) and at $29 \mathrm{kyr}$ (Figure 17). These periodicities of 23-19 and $29 \mathrm{kyr}$, which are also clearly expressed in the $\delta^{18} \mathrm{O}$ record of this core (Figure 17), have been shown to be associated with climatic variability at low latitudes and, especially, monsoon variability [e.g., Clemens and Prell, $1991 \mathrm{a}, \mathrm{b}]$. Little concentration of variance in the preservation record of core MD900963 is associated with the Milankovitch eccentricity and obliquity periods. As was already noted for 


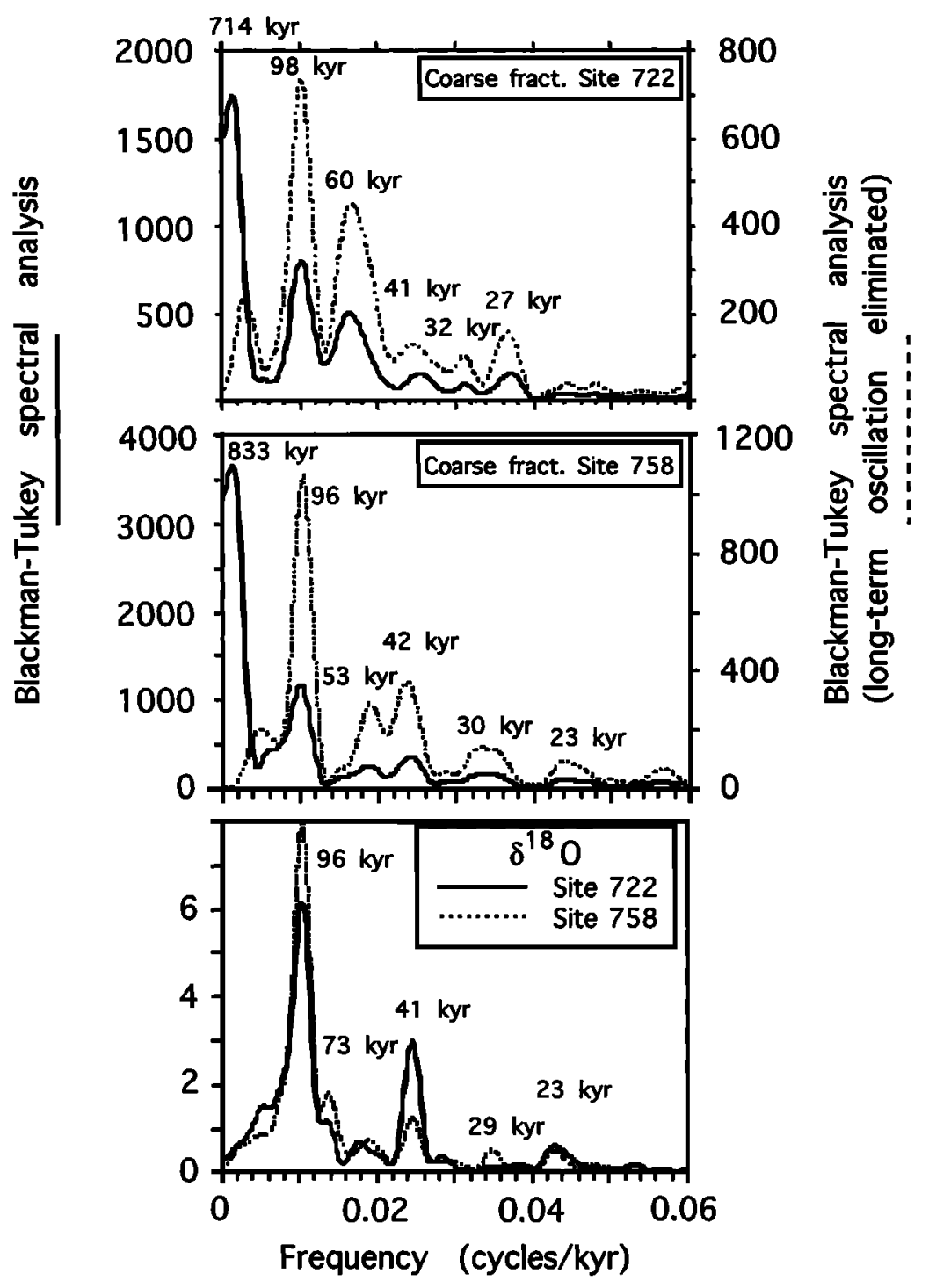

Figure 15. Blackman-Tukey spectral analysis of $900-\mathrm{kyr} \delta^{18} \mathrm{O}$ and coarse fraction records from sites 722 and 758. Dashed lines in the coarse fraction spectral analyses indicate the power spectra calculated after the longterm oscillation has been eliminated to resolve more accurately the high-frequency cycles (see text for details).

sites 722 and 758 , dissolution has only a subordinate effect on carbonate content in core MD900963. Hence the power spectrum of the carbonate content record differs clearly from that of the preservation index, with the highest spectral density found in the eccentricity band (95 kyr) (Figure 17). This suggests that high-frequency cycles in the preservation and the coarse fraction records from core MD900963 occur with little total loss of $\mathrm{CaCO}_{3}$ to dissolution.

Organic carbon $\left(\mathrm{C}_{\text {org }}\right)$ measurements in the top $10 \mathrm{~m}$ of core MD900963 (last $170 \mathrm{kyr}$ ) show that the high-frequency dissolution pulses observed in the foraminiferal fragmentation (or in grain size) are associated with changes in $\mathrm{C}_{\text {org }}$ content (e.g., high dissolution is observed in levels with high $\mathrm{C}_{\mathrm{org}}$ content) (Figure 18). Dissolution maxima and high organic carbon contents are associated with even-numbered $\delta^{18} O$ stages and a particularly well-marked maximum is shown in glacial stage 6 (Figure 18). The occurrence of a dissolution maximum in glacial stages is opposite to what has been observed at sites 722 and 758.

Strong evidence supports the hypothesis that fluctuations in organic carbon content in the sediments reflect changes in paleoproductivity [e.g., Müler and Suess, 1979; Bertrand and Lallier-Vergès, 1993]. However, only a small amount of the $C_{\text {org }}$ rain to the seafloor is ultimately preserved in the sediments (about 0.1 to $2 \%$ in sediments accumulating at 2 to $13 \mathrm{~cm} \mathrm{kyr}^{-1}$ [Müller and Suess, 1979]). Thus we suggest that high-frequency dissolution pulses observed in core MD900963 may be controlled ultimately by the oxidation of organic matter incorporated into the sediments in greater quantities during periods of high productivity [Emerson and Bender, 1981]. Sedimentation rates in core MD900963 are higher during odd-numbered $\delta^{18} \mathrm{O}$ stages than during even-numbered stages, thus better preservation of $\mathrm{C}_{\text {org }}$ through rapid burial cannot be invoked to explain higher $\mathrm{C}_{\text {org }}$ contents. Further 


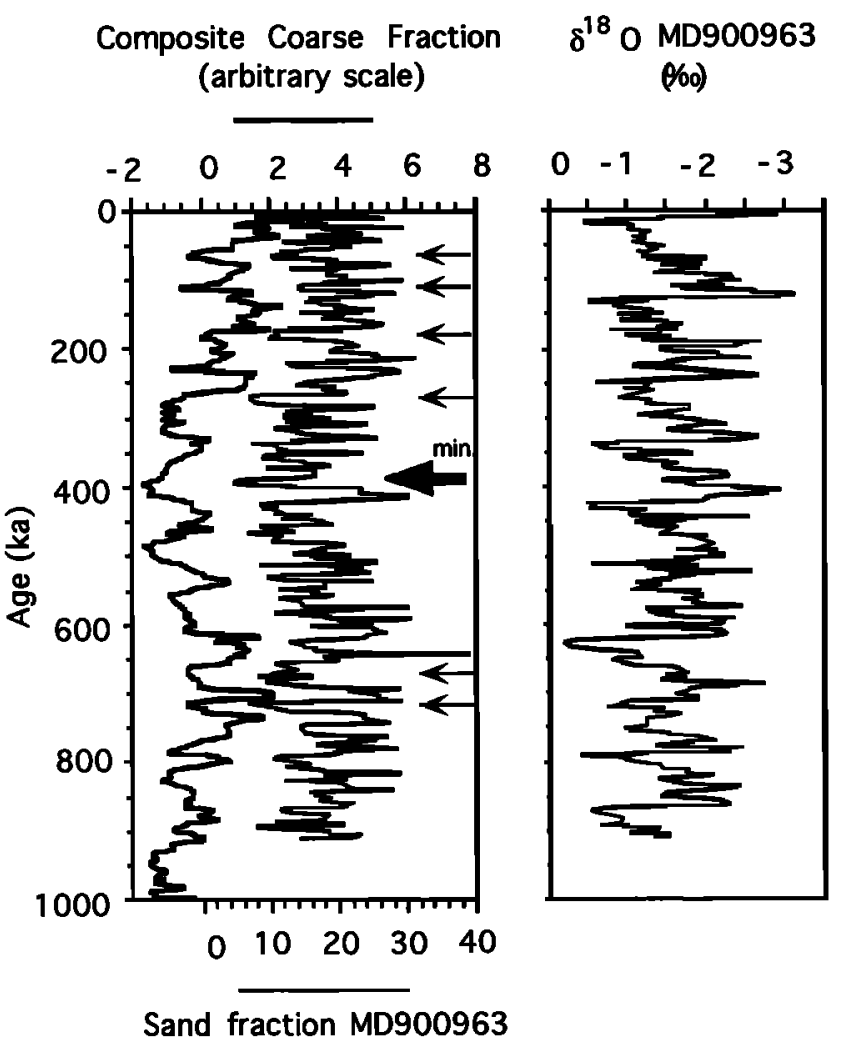

(\%)

Figure 16. (left) Plots versus age of the Composite Coarse Fraction Index curve (CCFI) and the high-resolution coarse fraction record from core MD900963 over the last $900 \mathrm{kyr}$. (right) Plot of $\delta^{18} \mathrm{O}$ versus age for core MD900963.

work is necessary to test this hypothesis and especially to quantify the amount of carbonate dissolved by such a process. Nevertheless, we contend that the amount required is probably small, since changes in dissolution, which are clearly reflected in foraminiferal fragmentation and grain size, do not noticeably affect the carbonate content of core MD900963 (see above).

Additional work is required to understand what ultimately controls those changes in paleoproductivity. At present, the $\mathrm{C}_{\text {org }}$ content record of core MD900963 is not long enough (last $170 \mathrm{kyr}$ ) to permit a precise spectral analysis. However, the strong precession-related cycles and the 29-kyr cycle we found in the carbonate dissolution record (foraminiferal fragmentation) argue for a low-latitude process which is most probably related to changes in the monsoonal system [Murray and Prell, 1992]. Using a combination of oxygen isotopes and alkenone-derived temperatures measured in the uppermost $10 \mathrm{~m}$ of core MD900963, Rostek et al. [1993] reconstructed the sea surface salinity signal for the Maldives area over the last $\mathbf{1 7 0}$ kyr. Today, the precipitation over India and the Indian Ocean is related to the strength of the SW monsoon [Cadet and Reverdin, 1981]. Hence Rostek et al. [1993] interpreted the variations in salinity recorded in core MD900963 as linked to past changes in the Indian monsoon. They found low salinity during stage $5 \mathrm{e}$ and the early Holocene, thus suggesting that the wet SW monsoon was stronger during these time intervals.

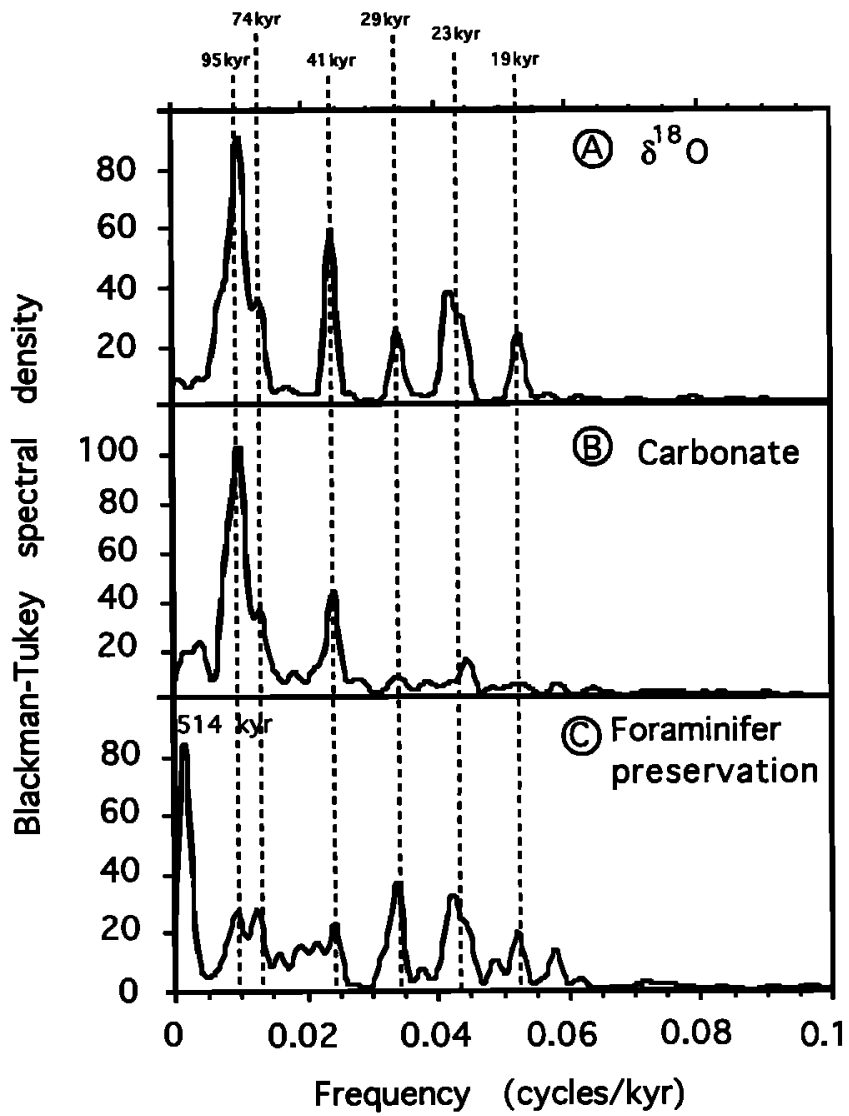

Figure 17. Blackman-Tukey spectral density of $\delta^{18} \mathrm{O}$, carbonate content, and foraminiferal preservation records in core MD900963.

Higher salinity were observed during glacial stages 6 and 2 and substage $5 \mathrm{~b}$, indicating reduced $\mathrm{SW}$ monsoon and/or increased dry SE monsoon.

Based on results from Rostek et al. [1993], it appears therefore that productivity generally increased (high $\mathrm{C}_{\text {org }}$ content) during periods of weak SW monsoon and/or strengthened NE monsoon. Whether the changes in productivity are regional or local is still under debate. Studies of primary productivity conducted in the modern Indian Ocean [e.g., Krey, 1973] indicate that south of India, the $C_{\text {org }}$ fluxes are highest during the SW monsoon and seem to be related to an upwelling cell which is clearly observed in SST records [Wyrtki, 1971]. Rao and Jayaraman [1966], however, showed that local upwelling cells may also develop during the NE monsoon season in the vicinity of the Maldives area. Thus if productivity changes are local in extent, we suggest that increased productivity during even-numbered $\delta^{18} \mathrm{O}$ stages may be related to the intensification of upwelling cells driven by NE monsoon winds. This hypothesis is in good agreement with the results of Fontugne and Duplessy [1986], who have shown that productivity during the last glacial period was greater in areas where production depends on the NE monsoon (such as upwelling off the NE coast of India).

It is puzzling that such a high-frequency dissolution signal related to $C_{o r g}$ decay is not observed at site 722 . The $C_{\text {org }}$ content of site 722 [Murray and Prell, 1991] has a higher mean 


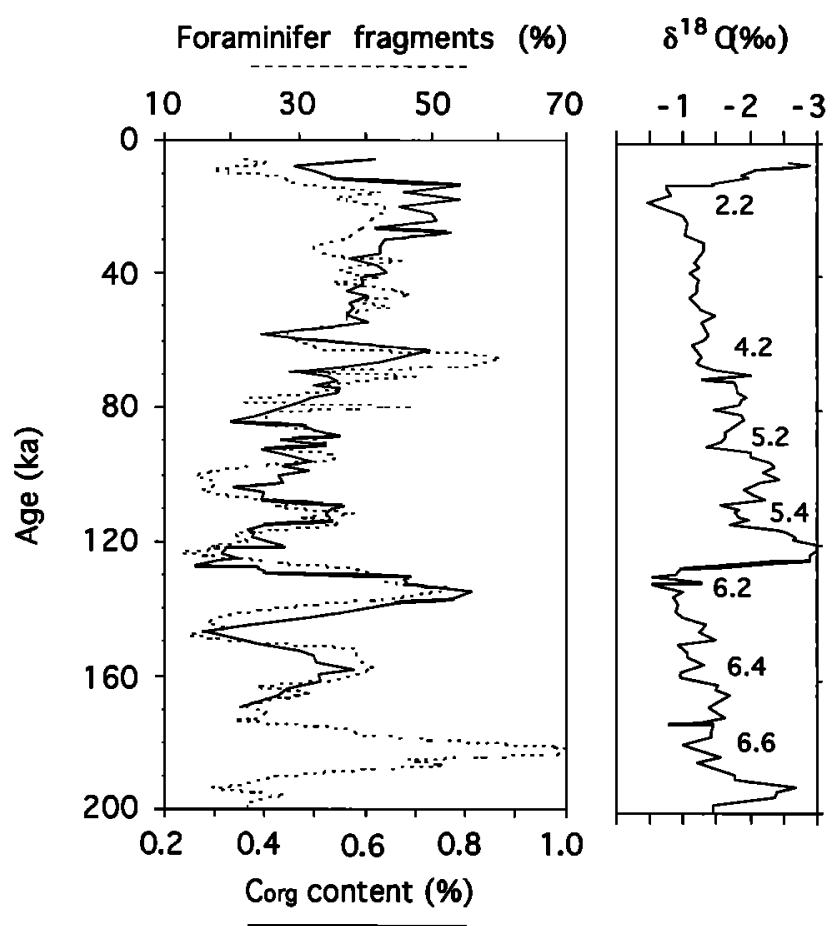

Figure 18. Plots of age versus $C_{\text {org }}$ content and percent of foraminiferal fragments (left) and versus $\delta^{18} O$ (right) over the last $200 \mathrm{kyr}$ in core MD900963.

value and shows higher-amplitude variability than that from core MD900963 (mean value is $-1 \%$ with a standard deviation of $0.43 \%$ for site 722 and $0.5 \%$ with a standard deviation of $0.12 \%$ for core MD900963). Furthermore, site 722 is situated in an area where primary productivity shows important seasonal changes which result from fluctuations of the monsoonal wind-driven Arabian upwelling. Thus we might expect to find precession-related changes in the $\mathrm{C}_{\text {org }}$ supply and the dissolution record from site 722. Nevertheless, the precession-related dissolution signal which is clearly observed in the grain size record of core MD900963 is absent in the grain size record from site 722 . Both sections were sampled at roughly $10-\mathrm{cm}$ intervals. The lower sedimentation rates at site 722 result in lower temporal resolution which most probably degrades the high-frequency signals. However, as discussed above, the spectral analysis of the oxygen record of site 722 shows a 23-kyr peak, thus indicating that the sedimentary section seems to permit the recovery of precession-related signals when they exist. Additional studies are necessary to know if the high-frequency dissolution signal observed in core MD900063 as well as the good correlation between coarse fraction content, foraminiferal fragmentation, and $\mathrm{C}_{\text {org }}$ content are observed at other locations.

\section{The Long-Term Dissolution Oscillation}

The major characteristic of coarse fraction records over the last $1500 \mathrm{kyr}$ is the high-amplitude, 500-kyr oscillation which reflects long-term changes in carbonate dissolution (Figures 4 and 9). This -500-kyr oscillation is superimposed on a gradual increase in mean coarse fraction content which is observed over the last $2500 \mathrm{kyr}$ in cores MD900938 and MD900940, at site 758, and especially at site 722 (Figure 4). Farrell and Prell [1991], who observed such a long-term increase of carbonate preservation in pelagic sediments from the Pacific, proposed that it results from a gradual lowering of sea level which fractionates carbonate from the world's shelves to the basins [e.g., Berger, 1970; Berger and Winterer, 1974].

A late Pleistocene $\mathbf{5 0 0 - k y r}$ dissolution oscillation has been previously observed by Vincent [1981] and Gardner [1982] in carbonates from the deep Pacific and was recently found in aragonite-bearing periplatform deposits from the Bahamas [Droxler et al., 1988] and the Maldives [Droxler et al., 1990]. The last $700 \mathrm{kyr}$ of this long-term oscillation correspond to the well-known "mid-Brunhes dissolution cycle" [Adelseck, 1977], with its characteristic dissolution maximum (grain size minimum) centered at about $400 \mathrm{ka}$ and bounded by preservation maxima (grain size maxima) at about $100 \mathrm{ka}$ and $700 \mathrm{ka}$. This cycle has been recognized in the Pacific [Vincent, 1981, 1985; Farrell and Prell, 1989], the north Atlantic [Crowley, 1985], and the equatorial Indian Ocean [Peterson and Prell, 1985a], clearly indicating its global character. MidBrunhes climatic cycles have been also observed in numerous other marine and continental records [Jansen et al., 1986]. Data from Vincent [1981] and Droxler et al. [1990] suggest that the mid-Brunhes interval may be part of a long-term oscillation and not a steplike phenomenon as proposed recently by different authors [Jansen et al., 1986; Chuey et al., 1987; Pisias and Rea, 1988].

Droxler et al. [1990] indicate that a $\sim 500-\mathrm{kyr}$ carbonate dissolution supercycle is recorded for at least the past $2000 \mathrm{kyr}$ in aragonite bearing periplatform sediments. However, our coarse fraction data suggest that high-amplitude oscillations that are correlatable across the tropical Indian Ocean apparently initiated at about $1400 \mathrm{ka}$. Prior to that time, only the site 758 record presents evidence for a long-term oscillation (Figure 4), but minima and maxima of this oscillation do not correlate well with minima and maxima of the aragonite supercycles described by Droxler et al. [1990]. For example, a maximum in the site 758 grain size record at about $2.0 \mathrm{Ma}$ corresponds to a strong minimum in aragonite supercycles, and a minimum in grain size at about $1.75 \mathrm{Ma}$ corresponds to a maximum in aragonite supercycles (it is interesting to note, however, that fine aragonite content of ODP hole $633 \mathrm{~A}$ in the Bahamas shows a strong minimum at about 1.75 Ma [Droxler et al., 1990]).

In the 0-1500 ka interval, the timing of minima and maxima in the aragonite supercycles [Droxler et al., 1990] appears to correlate quite nicely with that of minima and maxima in the CCFI curve (Table 3). The CCFI curve, whose ages rest upon correlations to the recent age model developed from site 677 [Shackleton et al., 1990], permits us to determine more accurately the ages of these minima and maxima. The longterm dissolution oscillation does not have a regular 500-kyr periodicity. Time intervals between two adjacent peaks or troughs vary from 425 to 550 kyr (Figure 14 and Table 3). We do not know yet if the long-term dissolution oscillation is a slightly irregular cycle, if it results from the distortion of a long-term supercycle by discrete events, or if it is the sum of independent events.

The high-amplitude dissolution oscillation implies important reorganizations of the oceanic carbon-carbonate 
Table 3. Ages of Minima and Maxima in the Long-Term Carbonate Dissolution Oscillation as Proposed by Droxler et al. [1990] and in This Study

\begin{tabular}{ccccc}
\hline $\begin{array}{c}\text { Maxima Carbonate Preservation } \\
\text { Ma }\end{array}$ & & \multicolumn{2}{c}{$\begin{array}{c}\text { Minima Carbonate Preservation } \\
\text { Ma }\end{array}$} \\
\cline { 1 - 2 } $\begin{array}{c}\text { Droxler et al. } \\
{[1990]}\end{array}$ & This Study & & $\begin{array}{c}\text { Droxler et al. } \\
{[1990]}\end{array}$ & This Study \\
\hline 0.15 & & & 0.40 & 0.40 \\
0.65 & 0.15 & & 0.90 & 0.95 \\
1.20 & 0.70 & & 1.45 & 1.40 \\
\hline
\end{tabular}

system in the early Pleistocene. At present, the mechanism involved in this large oscillation remains poorly understood. The onset of the long-term dissolution oscillation at about $1300-1500 \mathrm{ka}$ corresponds roughly to the onset of largeamplitude oscillations of North Atlantic Deep Water (NADW) production, with important reductions of NADW during glacial intervals [Raymo et al., 1990]. Today, NADW accumulates $\mathrm{CO}_{2}$ oxidized from falling organic debris on its "grand journey" to the Pacific, resulting in an important asymmetry in $\mathrm{CO}_{2}$ distribution and water acidity between the deep waters of the Atlantic and those of the Indo-Pacific. We cannot rule out the possibility that changes in NADW production may have an effect on the global deep-sea carbonate budget. However, if NADW production played a major role in the long-term dissolution oscillation, we would also expect a strong asymmetrical effect in the dissolution pattern of the Atlantic and the Indo-Pacific, resulting from basin-basin fractionation [Berger, 1970; Volat et al., 1980; Crowley, 1985]. The fact that the "mid-Brunhes dissolution interval" and the dissolution intervals centered at about 950 and $1400 \mathrm{ka}$ are also observed at intermediate water depths in the Indo-Pacific ocean as well as in the Atlantic [Droxler et al., 1990] suggests that there is a control by transfers between global carbon-carbonate reservoirs rather than by changes in deep circulation.

There is some evidence in sequences of marine terraces for higher sea level at about -400 ka (stage 11) and at about 950 $1070 \mathrm{ka}$ (stages 25 and 31) [Pirazzoli et al., 1993]. However, the magnitude of sea level changes is still poorly constrained, and it is therefore highly speculative to explain the long-term dissolution oscillation as resulting from a simple shelf-basin carbonate fractionation. Thus the origin of the long-term dissolution oscillation is still unresolved. Any mechanism proposed to explain it, however, should fulfill two conditions: (1) It must affect the entire ocean, since the "mid-Brunhes dissolution cycle" and the dissolution intervals centered at about 950 and $1400 \mathrm{kyr}$ have been observed in the Indo-Pacific as well as in the Atlantic, and (2) it has to affect the entire water column, since the long-term dissolution oscillation is recognized in shallow aragonite-bearing periplatform deposits as well as in deep-sea carbonates.

Long-term increases in the $\mathrm{Ca}^{++}$flux to the oceans have been recently proposed to explain the progressive increase in carbonate preservation since the Pliocene [Raymo et al., 1988; Farrell and Prell, 1989]. If we assume a "steady state" ocean, mass balance constraints require $\mathrm{Ca}^{++}$input to be offset by $\mathrm{Ca}^{++}$ output via oceanic $\mathrm{CaCO}_{3}$ sedimentation, thus explaining the better deep-sea carbonate preservation. Raymo et al. [1988] proposed that rapid tectonic uplift of mountains and plateau regions during the last 5 m.y. may explain such an overall increase of the $\mathrm{Ca}^{++}$flux to the ocean via increased chemical and mechanical erosion. Although the details of past changes of $\mathrm{Ca}^{++}$flux to the oceans and erosion budgets are not well known, we suggest that the $-500-\mathbf{k y r}$ carbonate dissolution oscillation may be associated with changes in $\mathrm{Ca}^{++}$flux to the ocean. These changes would result either from long-term isostatic adjustment or tectonic activity and/or past changes in the intensity of chemical weathering. The latter hypothesis finds some support in the fact that numerous marine and continental climatic time series show that the "mid-Brunhes dissolution cycle" developed during a time of important climatic changes [Jansen et al., 1986].

\section{Conclusions}

Over the last $1500 \mathrm{kyr}$, major changes in coarse fraction content of pelagic carbonate sediments can be correlated over much of the tropical Indian Ocean from 2030-m to about 3700$m$ water depths. These changes in grain size are mainly controlled by carbonate dissolution through the breakdown of sand-sized foraminifera and the subsequent transfer of small fragments into the finer size fraction.

We constructed a Composite Coarse Fraction Index (CCFI) curve for the last $1500 \mathrm{kyr}$ by merging the normalized coarse fraction records from ODP sites 722 (Owen Ridge, Arabian Sea) and 758 (Ninetyeast Ridge, eastern equatorial Indian Ocean). A precise chronostratigraphy of this composite curve was developed by correlating the $\delta^{18} \mathrm{O}$ records of sites 722 and 758 to the orbital chronology recently developed from ODP site 677 [Shackleton et al., 1990]. The CCFI curve, in which local grain size signals (winnowing and productivity) tend to cancel out, enhances the regional (or global) signal related to changes in carbonate dissolution. The last $800 \mathrm{kyr}$ of the CCFI curve appear to compare extremely well with the Composite Dissolution Index (CDI) curve from core V34-53 (Ninetyeast Ridge), which unambiguously records past variations of carbonate dissolution in the equatorial Indian Ocean [Peterson and Prell, 1985a].

In the late Pleistocene, the CCFI variations are mainly associated with glacial-interglacial changes. Frequency spectra show strong 100-kyr and 41-kyr periodicities but little precession-related response. As proposed by Peterson and Prell [1985a], the lack of a clear signal in the precessional bands suggests that the regional carbonate dissolution signal is driven by changes in deepwater circulation. However, additional higher-resolution studies are necessary at ODP sites 722 and 758, since we cannot totally reject the possibility that bioturbation and the relatively low temporal resolution at which these series were sampled degrade somehow the precession-related signals.

In contrast, spectral analyses of dissolution cycles in the giant (53 m long) piston core MD900963 (Maldives area) display clear maxima centered on the precession frequencies ( 23 and $19 \mathrm{kyr}^{-1}$ ) as well as on the $29-\mathrm{kyr}^{-1}$ frequency but show little power at the $100-\mathrm{kyr}^{-1}$ frequency. These high-frequency changes most probably result from changes in surface productivity associated with monsoon variability. Dissolution at this site may be ultimately controlled by the oxidation of 
organic matter which appears to be incorporated into the sediments in greater quantity during periods of weak SW monsoon and/or increased dry NE monsoon.

The CCFI record displays a long-term, high-amplitude dissolution oscillation, with the well-known "mid-Brunhes dissolution cycle" representing the last part of this oscillation. It appears that this long-term oscillation, whose origin is not yet fully known, is not a true cycle and shows an irregular wavelength (of the order of $\sim 500 \mathrm{kyr}$ but varying from 425 to $550 \mathrm{kyr}$ ). We suggest that this oscillation may be associated with long-term changes in $\mathrm{Ca}^{++}$flux to the ocean.

Acknowledgments. We are grateful to G. A. Haddad for fruitful discussion in the early stage of this work and to L. C. Peterson and an anonymous reviewer for constructive criticisms which helped to improve the manuscript. We thank all the members of the SEYMAMA expedition, both scientists and technicians, and especially Y. Balut from IFRTP for the development and operation of the giant coring system. Special thanks go to $\mathrm{N}$. Buchet for help in sample preparation and fragmentation data generation, and to $M$. Paterne, B. LeCoat, and J. Antignac for help in the isotopic analyses. F. B. expresses special thanks to his wife Christine who spent a large part of her holidays helping with grain size measurements. This work was supported by funding from INSU/CNRS under DBT and IST programs. This is contribution $\mathrm{n}^{\circ} 702$ of DBT, $n^{\circ} 94011$ of LGQ, and $n^{\circ} 1587$ of CFR.

\section{References}

Adelseck, C. G. Jr., Recent and late Pleistocene sediments from the eastern equatorial Pacific Ocean: Sedimentation and dissolution, Ph.D. thesis, 192 pp., Univ. of Calif., San Diego, 1977.

Arrhenius, G. O. S., Sediment cores from the east Pacific, Rep. Swed. Deep Sea Exped., 1947-1948, 5, 1-202, 1952.

Arrhenius, G. O. S., Rate of production, dissolution and accumulation of biogenic solids in the ocean, Palaeogeogr. Palaeoclimatol. Palaeoecol., 67, 119-146, 1988.

Bassinot, F. C., Analyse paléocéanographique à haute résolution des carbonates pélagiques des océans Indien et Pacifique en région tropicale, Ph.D. thesis, 230 pp., Univ. Aix-Marseille II, Marseille, France, 1993a.

Bassinot, F. C., Sonostratigraphy of tropical Indian Ocean giant piston cores: Toward a rapid and high-resolution tool for tracking dissolution cycles in Pleistocene carbonate sediments, Earth Planet. Sci. Lett., $120,327-344,1993 b$.

Bassinot, F. C., L. Beaufort, Y. Lancelot, and E. Vincent, Sonostratigraphy of equatorial Indian Ocean giant piston cores: Toward a rapid and high-resolution tool for tracking dissolution cycles in Pleistocene carbonate sediments, paper presented at Fourth International Congress on Paleo-Oceanography, Kiel, Germany, Sept. 21-25, 1992.

Be, A. W. H., J. W. Morse, and S. M. Harrison, Progressive dissolution and ultrastructural breakdown of planktonic foraminifera, in Dissolution of Deep-Sea Carbonates, edited by W. V. Sliter, A. W. H. Bé, and W. H. Berger, Spec. Publ. Cushman Found. Foraminiferal Res., 13, 27-55, 1975.

Be, A. W. H., J. E. Damuth, L. Lott, and R. Free, Late Quaternary climatic record in western equatorial Atlantic sediment, in Investigation of Late Quaternary Paleoceanography and Paleoclimatology, edited by R. F. Cline and J. D. Hays, Geol. Soc. Am. Mem., 145, 165-200, 1976.

Berger, W. H., Planktonic foraminifera: Selective solution and paleoclimatic interpretation, Deep Sea Res., 15, 31-43, 1968.

Berger, W. H., Biogenous deep-sea sediments: Fractionation by deepsea circulation, Geol. Soc. Am. Bull., 81, 1385-1402, 1970.

Berger, W. H., Deep-sea carbonates: Pleistocene dissolution cycles, $J$. Foraminiferal Res., 3, 187-195, 1973.
Berger, W. H., Deep-sea carbonate and the late deglaciation preservation spike in pteropods and foraminifera, Nature, 269, 301304, 1977.

Berger, W. H., Pacific carbonate cycles revisited: Arguments for and against productivity control, in Centenary of Japanese Micropaleontology, edited by F. Ishizaki and T. Saito, pp. 15-25, Terra Scientific, Tokyo, 1992.

Berger, W. H., and E. Vincent, Chemostratigraphy and biostratigraphic correlation: Exercises in systemic stratigraphy, Oceanol. Acta, supplement to vol. 4, 115-127, 1981.

Berger, W. H., and E. L. Winterer, Plate stratigraphy and the fluctuating carbonate line, in Pelagic Sediments on Land and Under the Sea, edited by K. J. Hsü and H. C. Jenkyns, Spec. Publ. Int. Assoc. Sedimentol., 1, 11-48, 1974.

Berger, W. H., C. G. Adelseck, and L. A. Mayer, Distribution of carbonate in surface sediments of the Pacific Ocean, $J$. Geophys. Res., 81, 2617-2627, 1976.

Berger, W. H., M.-C. Bonneau, and F. L. Parker, Foraminifera on the deep-sea floor: Lysocline and dissolution rate, Oceanol. Acta., 5, 249258, 1982.

Berggren, W. A., D. V. Kent, and J. A. Van Couvering, The Neogene, 2, Neogene geochronology and chronostratigraphy, in The Chronology of the Geological Record, edited by N. J. Snelling, Geol. Soc. London. Mem., 10, 21-260, 1985.

Bertrand, P., and E. Lallier-Vergès, Past sedimentary organic matter accumulation and degradation controlled by productivity, Nature, 364 , 786-788, 1993.

Biscaye, P. E., V. Kolla, and K. K. Turekian, Distribution of calcium carbonate in surface sediments of the Atlantic Ocean, J. Geophys. Res., 81, 2595-2603, 1976.

Boardman, M. R., and A. C. Neumann, Sources of periplatform carbonate: Northwest Providence Channel, Bahamas, J. Sediment. Petrol., 54, 1110-1112, 1984.

Boyle, E. A., Vertical oceanic nutrient fractionation and glacial/interglacial $\mathrm{CO}_{2}$ cycles, Nature, 331, 55-56, 1988.

Briggs, K. V, M. D. Richardson, and D. K. Young, Variability in geoacoustic and related properties of surface sediments from the Venezuela Basin, Caribbean Sea, Mar. Geol., 68, 73-106, 1985.

Broecker, W. S., Calcite accumulation rates and glacial to interglacial changes in the oceanic mixing, in The Late Cenozoic Glacial Ages, edited by K. K. Turekian, pp. 239-265, Yale University Press, New Haven, 1971.

Broecker, W. S., Glacial to interglacial changes in ocean chemistry, in Climatic Variability in the Oceans, edited by E. B. Krauss and H. P. Hanson, Prog. Oceanogr., 11, 151-197, 1982.

Broecker, W. S., and T. H. Peng. Tracers in the Sea, 690 pp., LamontDoherty Earth Observatory Press, Palisades, N. Y., 1982.

Broecker, W. S., and T. H. Peng, The role of $\mathrm{CaCO}_{3}$ compensation in the glacial to interglacial atmospheric $\mathrm{CO}_{2}$ change, Global Biogeochem. Cycles, 1, 15-29, 1987.

Cadet, D., and G. Reverdin, Water vapour transport over the Indian Ocean during summer 1975, Tellus, 33(5), 476-487, 1981.

Chen, M.-T., and J. W. Farrell, Planktonic foraminifer faunal variations in the northeastern Indian Ocean: A high resolution record of the past 800,000 years from site 758, Proc. Ocean Drill. Program. Sci. Results, 121, 125-140, 1991.

Chuey, J. M., D. K. Rea, and N. G. Pisias, Late Pleistocene paleoclimatology of the central equatorial Pacific, a quantitative record of eolian and carbonate deposition, Quat. Res., 28, 323-339, 1987.

Clemens, S. C., and W. L. Prell, One million year record of summer monsoon winds and continental aridity from the Owen Ridge (site 722), northwest Arabian Sea, Proc. Ocean Drill. Program, Sci. Results, 117, 365-388, 1991a.

Clemens, S. C., and W. L. Prell, Late Quaternary forcing of the Indian summer monsoon winds: A comparison of Fourier model and general circulation model results, J. Geophys. Res., 96, 22,683-22,700, $1991 \mathrm{~b}$. 
Crowley, T. J., Depth-dependent carbonate dissolution changes in the eastern North Atlantic during the last 170,000 years, Mar. Geol., 54, 25-31, 1983.

Crowley, T. J., Late Quaternary carbonate dissolution changes in the North Atlantic and Atlantic/Pacific comparisons, in The Carbon Cycle and Atmospheric $\mathrm{CO}_{2}$ : Natural Variations Archean to Present, Geophys. Monogr. Ser., vol. 32, edited by E. Sundquist and W. Broecker, pp. 271-284, AGU, Washington, D. C., 1985.

Cullen, J. L., and W. L. Prell, Planktonic foraminifera of the northern Indian Ocean: Distribution and preservation in surface sediments, Mar. Micropaleontol., 9, 1-52, 1984.

Droxler, A. W., W. Schlager, and C. C Whallon, Quaternary aragonite cycles and oxygen-isotope records in Bahamian carbonate ooze, Geology, 11, 235-239, 1983.

Droxler, A. W., C. H. Bruce, W. W. Sager, and D. H. Watkins, Pliocene-Pleistocene variations in aragonite content and planktonic oxygen-isotope record in Bahamian periplatform ooze, hole 633A, Proc. Ocean Drill. Program, Sci. Results, 101, 221-244, 1988.

Droxler, A. W., G. A. Haddad, D. A. Mucciarone, and J. L. Cullen, Pliocene-Pleistocene aragonite cyclic variations in holes 714A and 716B (the Maldives) compared with hole 633A (the Bahamas): Records of climate-induced $\mathrm{CaCO}_{3}$ preservation at intermediate water depths, Proc. Ocean Drill. Program. Sci. Results, 115, 539-567, 1990

Emerson, S., and M. Bender, Carbon fluxes at the sediment-water interface of the deep-sea: Calcium carbonate preservation, J. Mar. Res., 39, 139-162, 1981.

Farrell, J. W., Late Neogene paleoceanography of the central equatorial pacific: Evidence from carbonate preservation and stable isotopes, Ph.D. thesis, 508 pp., Brown Univ., Providence, R. 1., 1991.

Farrell, J. W., and T. R. Janecek, Late Neogene paleoceanography and paleoclimatology of the northeast Indian Ocean (site 758), Proc. Ocean Drill. Program Sci. Results, 121, 297-355, 1991.

Farrell, J. W., and W. L. Prell, Climatic change and $\mathrm{CaCO}_{3}$ preservation: An 800,000 year bathymetric reconstruction from the central Pacific Ocean, Paleoceanography, 4, 447-466, 1989.

Farrell, J. W., and W. L. Prell, Pacific $\mathrm{CaCO}_{3}$ preservation and $\delta^{18} \mathrm{O}$ since 4 Ma: Paleoceanographic and paleoclimatic implications, Paleoceanography, 6, 485-498, 1991.

Fontugne, M., and J. C. Duplessy, Variations of the monsoon regime during the upper Quaternary: Evidence from carbon isotopic record of organic matter in north Indian Ocean sediment cores, Palaeogeogr. Palaeoclimat. Palaeoecol., 56, 69-88, 1986.

François, R., M. P. Bacon, and D. O. Suman, Thorium 230 profiling in deep-sea sediments: High-resolution records of flux and dissolution of carbonate in the equatorial Atlantic during the last 20,000 years, Paleoceanography, 8, 761-787, 1990.

Gardner, J. V., Late Pleistocene carbonate dissolution cycles in the eastern equatorial Atlantic, in Dissolution of Deep-Sea Carbonates, edited by W. V. Sliter, A. W. H. Bé, and W. H. Berger, Spec. Publ. Cushman Found. Foraminiferal Res., 13, 129-141, 1975.

Gardner, J. V., High-resolution carbonate and organic-carbon stratigraphies for the Late Neogene and Quaternary from the western Caribbean and eastern equatorial Pacific, In: Prell, W. L., Gardner, J. V., et al., Initial Rep. Deep Sea Drill. Proj., 68, 347-364, 1982.

Haddad, G. A., A study of carbonate dissolution, stable isotope chemistry, and minor element composition of pteropods and foraminifers deposited in the Northwest Providence Channel, Bahamas, during the past 500,000 years, M.S. thesis, Duke Univ., Durham, N. C., 1986.

Hamilton, E. L., R. T. Bachman, W. H. Berger, T. C. Johnson, and L. A. Mayer, Acoustic and related properties of calcareous deep-sea sediments, J. Sediment. Petrol., 52, 733-753, 1982.

Hays, J. D., T. Saito, N. D. Opdyke, and L. H. Burckle, PliocenePleistocene sediments of the equatorial Pacific: Their paleomagnetic, biostratigraphic and climatic record, Geol. Soc. Am. Bull., 80, 1481$1514,1969$.
Howard, W., and W. L. Prell, Late Quaternary $\mathrm{CaCO}_{3}$ preservation in the Southern Ocean (abstract), Eos Trans. AGU, 71, 43, 1990.

Imbrie, J., J. D. Hays, D. G. Martinson, A. McIntyre, A. C. Mix, J. J. Morley, N. G. Pisias, W. L. Prell, and N. J. Shackleton, The orbital theory of Pleistocene climate: Support from a revised chronology of the marine $\delta^{18} \mathrm{O}$ record, in Milankovitch and Climate, part 1, edited by A. Berger, J. Imbrie, J. Hays, G. Kukla, and B. Saltzman, pp. 269305, D. Reidel, Norwell, Mass., 1984.

Jansen, J. H. F., A. Kuijpers, and S. R. Troelstra, A mid-Brunhes climatic event: Long-term changes in global atmospheric and ocean circulation, Science, 232, 619-622, 1986.

Jenkins, G. M. , and D. G. Watts, Spectral Analysis and Its Applications, 552 pp., Holden-Day, Oakland, Calif., 1968.

Johnson, T. C., E. L. Hamilton, and W. H. Berger, Physical properties of calcareous ooze: Control by dissolution at depth, Mar. Geol., 24, 259277, 1977.

Karlin, R., M. Lyle, and R. Zahn, Carbonate variations in the northeast Pacific during the late Quaternary, Paleoceanography, 7, 43-61, 1992.

Keir, R. S., On the Late Pleistocene ocean geochemistry and circulation, Paleoceanography, 3, 413-445, 1988.

Kier, J. S., and O. H. Pilkey, The influence of sea-level changes on sediment carbonate mineralogy, tongue of the Ocean, Bahamas, Mar. Geol., 11, 189-200, 1971.

Kolla, V., A. W. H. Bé, and P. E. Biscaye, Calcium carbonate distribution in the surface sediments of the Indian Ocean, J. Geophys. Res., 81, 2605-2616, 1976.

Krey, J., Primary production in the Indian Ocean, in The Biology of the Indian Ocean, edited by B. Zeitzschel, pp. 115-126, Springer-Verlag, New York, 1973.

Le, J., and N. J. Shackleton, Carbonate dissolution fluctuations in the western equatorial Pacific during the late Quaternary, Paleoceanography, 7, 21-42, 1992.

Luz, B., and N. J. Shackleton, $\mathrm{CaCO}_{3}$ solution in the tropical Pacific during the past 130,000 years, in Dissolution of Deep-Sea Carbonates, edited by W. V. Sliter, A. W. H. Be, and W. H. Berger, Spec. Publ. Cushman Found. Foraminiferal Res., 13, 142-150, 1975.

Mayer, L. A., Deep-sea carbonates: acoustic, physical, and stratigraphic properties, J. Sediment. Petrol., 49, 819-836, 1979.

Mayer, L. A., E. Jansen, J. Backman, and T. Takayama, Climatic cyclicity at ODP site 806: The GRAPE record, Proc. Ocean Drill. Program Sci. Results, 130, 623-639, 1993.

Mienert, J., and J. Bloemendal, A comparison of acoustic and rockmagnetic properties of equatorial Atlantic deep-sea sediments: Paleoceanographic implications, Earth Planet. Sci. Lett., 94, 291-300, 1989.

Moore, T. C., N. G. Pisias, and G. R. Heath, Climate changes and lags in Pacific carbonate preservation, sea surface temperature and global ice volume, in The Fate of Fossil Fuel $\mathrm{CO}_{2}$ in the Oceans, edited by N. R. Andersen and A. Malahoff, pp. 145-165, Plenum, New York, 1977.

Moore, T. C., Jr., N. G. Pisias, and D. A. Dunn, Carbonate time series of the Quaternary and late Miocene sediments in the Pacific Ocean: A spectral comparison, Mar. Geol., 46, 217-233, 1982.

Müller, P. J., and E. Suess, Productivity, sedimentation rate, and sedimentary organic matter in the oceans, I, Organic carbon preservation, Deep Sea Res., 26, 1347-1362, 1979.

Müller, P. J., R. Schneider, and G. Ruhland, Late Quaternary $p \mathrm{CO}_{2}$ variations in the Angola current: evidence from organic carbon $\delta^{13} \mathrm{C}$ and alkenone termperatures, in Carbon Cycling in the Glacial Ocean: Constraints on the Ocean's Role in Global Change, edited by R. Zahn, T. Pedersen, M. Kaminski, and L. Labeyrie, NATO ASI Ser., 17, 343 366, 1994.

Murray, D. W., and W. L. Prell, Pliocene to Pleistocene variations in calcium carbonate, organic carbon, and opal on the Owen Ridge, Northern Arabian Sea, Proc. Ocean Drill. Program, Sci. Results., 117, 343-355, 1991. 
Murray, D. W., and W. L. Prell, Late Pliocene and Pleistocene climatic oscillations and monsoonal upwelling recorded in sediments from the Owen Ridge, northwestern Arabian Sea, in Upwelling Systems: Evolution Since the Early Miocene, edited by W.L. Prell and K.C. Emeis, Geol. Soc. Spec. Publ., London, 64, 301-321, 1992.

Peirce, J., et al., Proc. Ocean Drill. Program, Init. Rep., I21, 1-1000, 1991.

Peterson, L. C., and W. L. Prell, Carbonate preservation and rates of climatic changes: An $800 \mathrm{kyr}$ record from the Indian Ocean, in the carbon Cycle and Amospheric $\mathrm{CO}_{2}$ : Natural Variations Archean to Present, Geophys. Monogr. Ser., vol. 32, edited by E. Sundquist and W. Broeker, pp. 251-269, AGU, Washington, D.C., 1985a.

Peterson, L. C., and W. L. Prell, Carbonate dissolution in recent sediments of the eastern equatorial Indian Ocean: Preservation patterns and carbonate loss above the lysocline, Mar. Geol., 64, 259290, 1985 b.

Pirazzoli, P. A., U. Radtke, W. S., Hantoro, C. Jouannic, C. T. Hoang, C. Causse, and $\mathrm{M}$. Borel Best, $A$ one million-year-long sequence of marine terraces on Sumba Island, Indonesia, Mar. Geol., 109, 221236, 1993.

Pisias, N. G., Geologic time series from deep-sea sediments: time scales and distortion by bioturbation, Mar. Geol., 51, 99-113, 1983.

Pisias, N. G., and D. K. Rea, Late Pleistocene paleoclimatology of the central equatorial Pacific: Sea surface response to the Southeast Trade Winds, Paleoceanography, 3, 21-37, 1988.

Prell, W. L., Oxygen and carbon isotope stratigraphy for the Quatemary of hole 502B: Evidence for two modes of isotopic variability, Initial Rep. Deep Sea Drill. Proj., 68, 455-464, 1982.

Prell, W. L., et al., Proc. Ocean Drill. Program, Init. Rep., 117, 1-1236, 1991.

Raffi, I., J. Backman, D. Rio, and N. Shackleton, Plio-Pleistocene nannofossil biostratigraphy and calibration to oxygen isotope stratigraphies from Deep Sea Drilling Project site 607 and ODP site 677, Paleoceanography, 88, 387-408, 1993.

Rao, L. V. G., and R. Jayaraman, Upwelling in the Minicoy region of the Arabian Sea, Curr. Sci., 35(15), 378-380, 1966.

Raymo, M. E., W. F. Ruddiman, and P. N. Froelich, Influence of the late Cenozoic mountain building on ocean geochemical cycles, Geology, 16, 649-653, 1988.

Raymo, M. E., W. F. Ruddiman, N. J. Shackleton, and D. W. Oppo, Evolution of the Atlantic-Pacific $\delta^{13} \mathrm{C}$ gradients over the last 2.5 m.y., Earth Planet. Sci. Lett., 97, 353-368, 1990.

Rostek, F., G. Ruhland, F. C. Bassinot, P. J. Müller, L. D. Labeyrie, Y. Lancelot, and E. Bard, Reconstructing sea surface temperature and salinity using $\delta^{18} \mathrm{O}$ and alkenone records, Nature, 364, 319-321, 1993.

Ruddiman, W. F., M. E. Raymo, D. G. Martinson, B. M. Clement, and J. Backman, Pleistocene evolution: Northern hemisphere ice sheets and North Atlantic Ocean, Paleoceanography, 4, 353-412, 1989.
Schlager, W., and N. P. James, Low-magnesian calcite limestones forming at the deep-sea floor, Tongue of the Ocean, Bahamas, Sedimentology, 15, 675-702, 1978.

Shackleton, N. J., Carbon-13 in Uvigerina: Tropical rainforest history and the equatorial Pacific dissolution cycles, in The Fate of Fossil Fuel $\mathrm{CO}_{2}$ in the Oceans, edited by N. R. Andersen and A. Malahoff, pp. 401-427, Plenum, New York, 1977.

Shackleton, N. J., A. Berger, and W. R. Peltier, An alternative astronomical calibration of the lower Pleistocene timescale based on ODP Site 677, Trans. R. Soc. Edinburgh Earth Sci., 81, 251-261, 1990.

Sundquist, E. T., and W. S. Broecker (Eds.), The Carbon Cycle and Atmospheric $\mathrm{CO}_{2}$ : Natural Variations Archean to Present, in Geophys. Monogr. Ser., vol. 32, 627 pp., AGU, Washington, D. C., 1985.

Thompson, P. R., and T. Saito, Pacific Pleistocene sediments: Planktonic Foraminifera dissolution cycles and geochronology, Geology, 2, 333335, 1974.

Thunell, R. C., Optimum indices of calcium carbonate dissolution in deep-sea sediments, Geology, 4, 525-527, 1976.

Vincent, E., Carbonate stratigraphy of Hess Rise, Central North Pacific and paleoceanographic implications, Initial Rep. Deep Sea Drill. Proj., 62, 571-606, 1981.

Vincent, E., Distribution stratigraphique de la teneur en carbonate dans les sédiments néogènes et quaternaires de l'Océan Pacifique, Bull. Soc. Geol. Fr., 8, 915-924, 1985.

Volat, J. L., L. Pastouret, and C. Vergnaud-Grazzini, Dissolution and carbonate fluctuations in Pleistocene deep-sea cores: A review, Mar. Geol., 34, 1-28, 1980.

Wei, W., Calibration of upper Pliocene-lower Pleistocene nannofossil events with oxygen isotope stratigraphy, Paleoceanography, 8, 85-99, 1993.

Wyrtki, K., Oceanographic Atlas of the Indian Ocean Expedition, National Science Foundation, Washington, D. C., 1971.

$\mathrm{Wu}, \mathrm{G}$., and W. H. Berger, Pleistocene $\delta^{18} \mathrm{O}$ records from Ontong Java Plateau: Effects of winnowing and dissolution, Mar. Geol., 96, 193209, 1991.

F. C. Bassinot and L. D. Labeyrie, Centre des Faibles Radioactivités, Domaine du CNRS, Avenue de la Terrasse BP 1, 91198 Gif-sur-Yvette, France.

L. Beaufort, Y. Lancelot, F. Rostek, and E. Vincent, Laboratoire de Géologie du Quaternaire, CNRS Luminy - Case 907, 13288 Marseille Cedex 09, France.

P. J. Müller, FB 5 - Geowissenschaften, Universität Bremen, D-28359 Bremen, Germany.

X. Quidelleur, Institut de Physique du Globe de Paris, Laboratoire de Géodynamique et Paléomagnétisme, Tour 24, 1er étage, 75252 Paris Cedex 05, France.

(Received February 19, 1993; revised March 28, 1994; accepted March 28, 1994.) 